\title{
Effects of spatial and temporal variability of turbidity on phytoplankton blooms
}

\author{
Christine L. May ${ }^{1, *}$, Jeffrey R. Koseff ${ }^{1}$, Lisa V. Lucas ${ }^{2}$, James E. Cloern², \\ David H. Schoellhamer ${ }^{3}$
}

\author{
${ }^{1}$ Department of Civil and Environmental Engineering, Stanford University, Stanford, California 94305-4020, USA \\ ${ }^{2}$ US Geological Service, 345 Middlefield Road, Menlo Park, California 94025, USA \\ ${ }^{3}$ US Geological Service, Placer Hall, 6000 J Street, Sacramento, California 95819-6129, USA
}

\begin{abstract}
A central challenge of coastal ecology is sorting out the interacting spatial and temporal components of environmental variability that combine to drive changes in phytoplankton biomass. For 2 decades, we have combined sustained observation and experimentation in South San Francisco Bay (SSFB) with numerical modeling analyses to search for general principles that define phytoplankton population responses to physical dynamics characteristic of shallow, nutrient-rich coastal waters having complex bathymetry and influenced by tides, wind and river flow. This study is the latest contribution where we investigate light-limited phytoplankton growth using a numerical model, by modeling turbidity as a function of suspended sediment concentrations (SSC). The goal was to explore the sensitivity of estuarine phytoplankton dynamics to spatial and temporal variations in turbidity, and to synthesize outcomes of simulation experiments into a new conceptual framework for defining the combinations of physical-biological forcings that promote or preclude development of phytoplankton blooms in coastal ecosystems. The 3 main conclusions of this study are: (1) The timing of the wind with semidiurnal tides and the spring-neap cycle can significantly enhance springneap variability in turbidity and phytoplankton biomass; (2) Fetch is a significant factor potentially affecting phytoplankton dynamics by enhancing and/or creating spatial variability in turbidity; and (3) It is possible to parameterize the combined effect of the processes influencing turbidity - and thus affecting potential phytoplankton bloom development-with 2 indices for vertical and horizontal clearing of the water column. Our conceptual framework is built around these 2 indices, providing a means to determine under what conditions a phytoplankton bloom can occur, and whether a potential bloom is only locally supported or system-wide in scale. This conceptual framework provides a tool for exploring the inherent light climate attributes of shallow estuarine ecosystems and helps determine susceptibility to the harmful effects of nutrient enrichment.
\end{abstract}

KEY WORDS: Estuaries - Coastal ecosystems - Light limitation · Turbidity - Phytoplankton · Numerical modeling $\cdot$ Coastal eutrophication $\cdot$ Nutrient enrichment

Resale or republication not permitted without written consent of the publisher

\section{INTRODUCTION}

Phytoplankton blooms in shallow turbid estuaries can vary in magnitude and duration as responses to variable river inflow, vertical and horizontal stratification, turbulent mixing, benthic and pelagic grazing, and nutrient and light availability. Bloom dynamics are further complicated in coastal ecosystems having large spatial gradients in these forcings, as well as in bathymetry. The growth environment of phytoplankton is either directly or indirectly set by the physical environment; therefore, phytoplankton biomass variability is highest in environments having complex physical dynamics. A central challenge of coastal ecology is to sort out the interacting spatial and temporal components of environmental variability that combine to drive changes in phytoplankton biomass. This is a first-order challenge because phytoplankton production is the biological engine that fuels production at higher trophic levels and drives biogeochemical variability (Cloern 1996). This challenge is of practical importance because phytoplankton biomass and pro- 
duction can increase in response to anthropogenic nutrient enrichment, leading to degraded water quality, increased frequencies of harmful blooms and loss of living resources (NRC 2000). We now recognize that the expression of nutrient enrichment is strongly influenced by the inherent physical properties of individual coastal ecosystems that shape, limit, or promote episodes of rapid phytoplankton growth (Cloern 2001).

The goal of this study is to explore the sensitivity of estuarine phytoplankton dynamics to spatial and temporal variations in turbidity where light availability, rather than nutrients, is the limiting factor to phytoplankton growth. The strong correlation between turbidity and suspended sediment concentrations (SSC) suggests that turbidity in many shallow estuaries is primarily a function of SSC (Cloern 1987). We therefore initiated a numerical modeling study to understand the interplay between the key mecha-

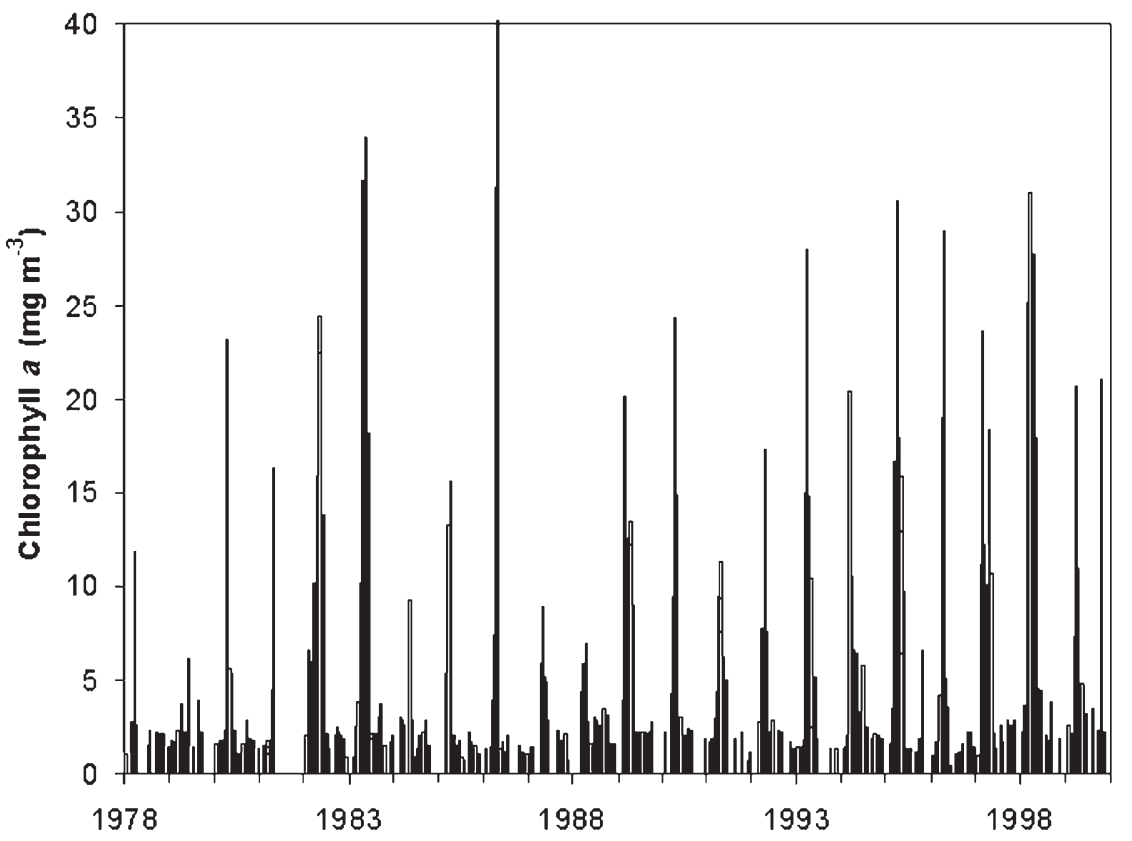

Fig. 1. Variability in spring bloom magnitude from year to year. Chlorophyll a series collected at USGS (US Geological Survey) Stn 27 in South San Francisco Bay. Source available at sfbay.wr.usgs.gov/access/wqdata/

nisms affecting SSC: wind, tides, sediment sinking, transport and stratification. Our numerical model was used as a diagnostic tool to tease apart the key mechanisms and understand the relative importance of each and their interaction. South San Francisco Bay (SSFB) was chosen as a representative system for our analyses because of the availability of high quality data based on over 2 decades of sustained observation, experimentation and numerical modeling analyses. This paper is the latest contribution in a series of numerical investigations focused on SSFB, motivated by our search for general principles that define phytoplankton population responses to physical dynamics characteristic of shallow, nutrient-rich, coastal waters having complex bathymetry and influenced by tides, wind and river flow.

A rigorous test of our evolving understanding of phytoplankton dynamics is our capacity to identify the processes of variability reflected in the continuing series of phytoplankton biomass measured as chlorophyll a (chl a) (see Fig. 1). The prominent spring blooms in this record are responses to episodic and seasonal changes in the balance between light-limited phytoplankton growth (Alpine \& Cloern 1988) and grazing losses to pelagic and (primarily) benthic grazers (Cloern 1982), where this balance is strongly controlled by tidally driven turbulent mixing (Cloern 1991), density stratification produced by horizontal salinity gradients during the rainy season (Koseff et al. 1993) and tidal-scale interactions between all these processes (Lucas et al. 1998). Moreover, the local

balance between phytoplankton production and sinks varies across the bathymetric gradient from the deep channel to the lateral shallows of SSFB (see Fig. 2), with the shallow regimes often (but not always) acting as net sources and the channel a net sink (Caffrey et al. 1998). Therefore, horizontal exchanges of phytoplankton biomass play a critical role in shaping the evolution of blooms and the spatial distributions of biomass (Lucas et al. 1999a,b).

Shallow regimes also play a critical role for SSC, where tidal forcing is generally weak and insufficient to resuspend sediment; however, SSC is typically greater on the shoals than the deeper channel due to the stronger influence of wind-wave resuspension (Grant \& Madsen 1979, Sanford 1994, Schoellhamer 1996). Although many estuary properties may be fairly constant (distinct sediment types, bed characteristics, etc.), temporal variability in wind (i.e. over a day, week, season) and spatial variability in sediment resuspension (i.e. due to fetch and depth limitations in windwave resuspension) can be quite dramatic (Ruhl et al. 2001).

While our previous research explains some important features of the chl a time series collected in SSFB (Fig. 1), such as the inception of blooms on neap tides and the occurrence of the largest blooms during wet years (e.g. 1982, 1983, 1986) because of strong persistent stratification in the channel, other features have not yet been explained; hence, our conceptual under- 


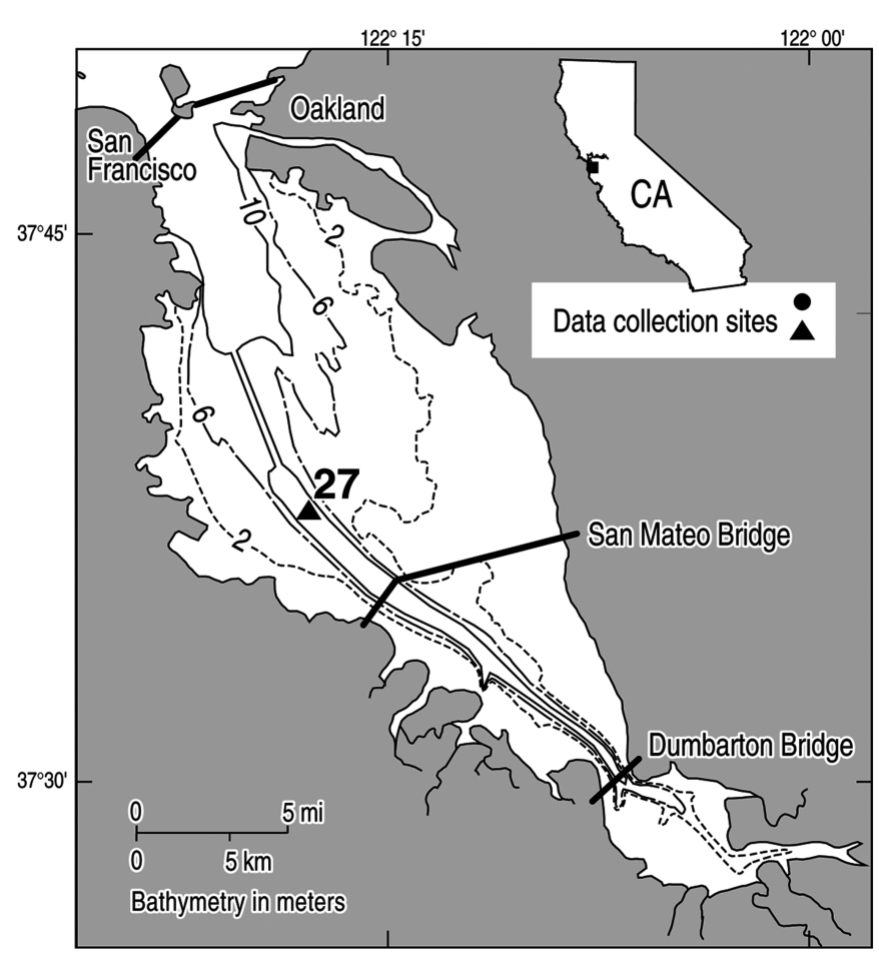

Fig. 2. South San Francisco Bay (SSFB) with depth contours and location of USGS Stn 27 in the channel

standing is incomplete. For example, reasons for the variability in the magnitude of the spring bloom during dry years, such as 1990 (relatively large bloom) and 1991 (small bloom), have not yet been identified with modeling analyses. This gap of understanding is critical because year-to-year variability in biomass corresponds to even larger variability in primary production; estimated March-April primary production is $67 \mathrm{gC} \mathrm{m}^{-2}$ for 1990 but only $18 \mathrm{~g} \mathrm{C} \mathrm{m}^{-2}$ for 1991 (see Fig. 3). This contrast between consecutive dry years serves as a natural experiment that yields clues about a missing mechanism - the timing and strength of the wind and its effect on light availability. We used this natural experiment as motivation to build into our evolving conceptual and numerical models explicit consideration of the wind as a component of the physical system that defines the growth habitat for phytoplankton in shallow coastal ecosystems.

The apparent effects of the variability of wind magnitude and direction (and, thereby, light availability) on phytoplankton bloom dynamics are illustrated in Fig. 3. In the spring of 1990 in SSFB, relatively calm wind speeds averaging about $4.5 \mathrm{~m} \mathrm{~s}^{-1}$ were prevalent during the critical period of minimum tidal energy (Fig. 3, March 31 to April 7) (critical period is defined as the period over which the $7 \mathrm{~d}$ running average of maximum daily current speed is minimum, see Fig. 3). This coincided with a period of low SSC and low values of light attenuation, and a period of rapid phytoplankton growth. During the analogous critical neap tide period of 1991, winds were stronger, averaging $7 \mathrm{~m} \mathrm{~s}^{-1}$ (Fig. 3, April 3 to 13), and turbidity (light attenuation) was elevated, presumably due to enhanced sediment resuspension in the shoals and subsequent transport to the channel. During spring 1991, the water column became too turbid for positive phytoplankton growth and the bloom was consequently damped.

With this natural experiment as motivation, our paper addresses the following question: How do(es) spatial and temporal variability in turbidity translate into variability in marine ecosystem response (i.e. phytoplankton growth or decline)? This question is central to our understanding of bloom dynamics in shallow estuaries. Variations in turbidity are shaped by estuarine geometry - the combination of shallow and deep domains, as well as the physical size of the estuary that determines the fetch at any point within the system. Variations in turbidity also occur due to interactions between physical and biological phenomena, each with their own characteristic timescales. Some of these phenomena affect vertical variability in turbidity (i.e. wind, tides, sediment sinking), and others affect horizontal variability in turbidity (i.e. horizontal transport). Our goal here is to conduct a strategic set of simulation experiments to develop general understanding of how physical forcings operating at different timescales interact to regulate estuarine bloom dynamics. This understanding will provide a foundation for explaining the high variability among coastal ecosystems in their responses to nutrient enrichment.

\section{METHODS}

Research approach. To investigate the effect of variable turbidity on phytoplankton dynamics, we developed a numerical model that includes phytoplankton and sediment dynamics, tidal hydrodynamics, and wind. Fig. 4 illustrates the basic components of our experimental design, and the set of processes included in our model. The main panel (1) depicts the 'base' mode in which we ran the model, and the 5 sub-panels each represent a separate numerical experiment to investigate spring-neap variability in tidal mixing and stratification in a deep channel ( 2 and 3 ), variability in wind magnitude and phasing (4), fetch (5), and lateral transport in a coupled channel-shoal system (6). In addition to exploring the effect of each mechanism individually, we performed 750 different $28 \mathrm{~d}$ numerical simulations where each simulation included a unique combination of the controlling parameters (i.e. sediment sinking rates, erodability, critical shear stress for erosion, stratification, water column depths, and 

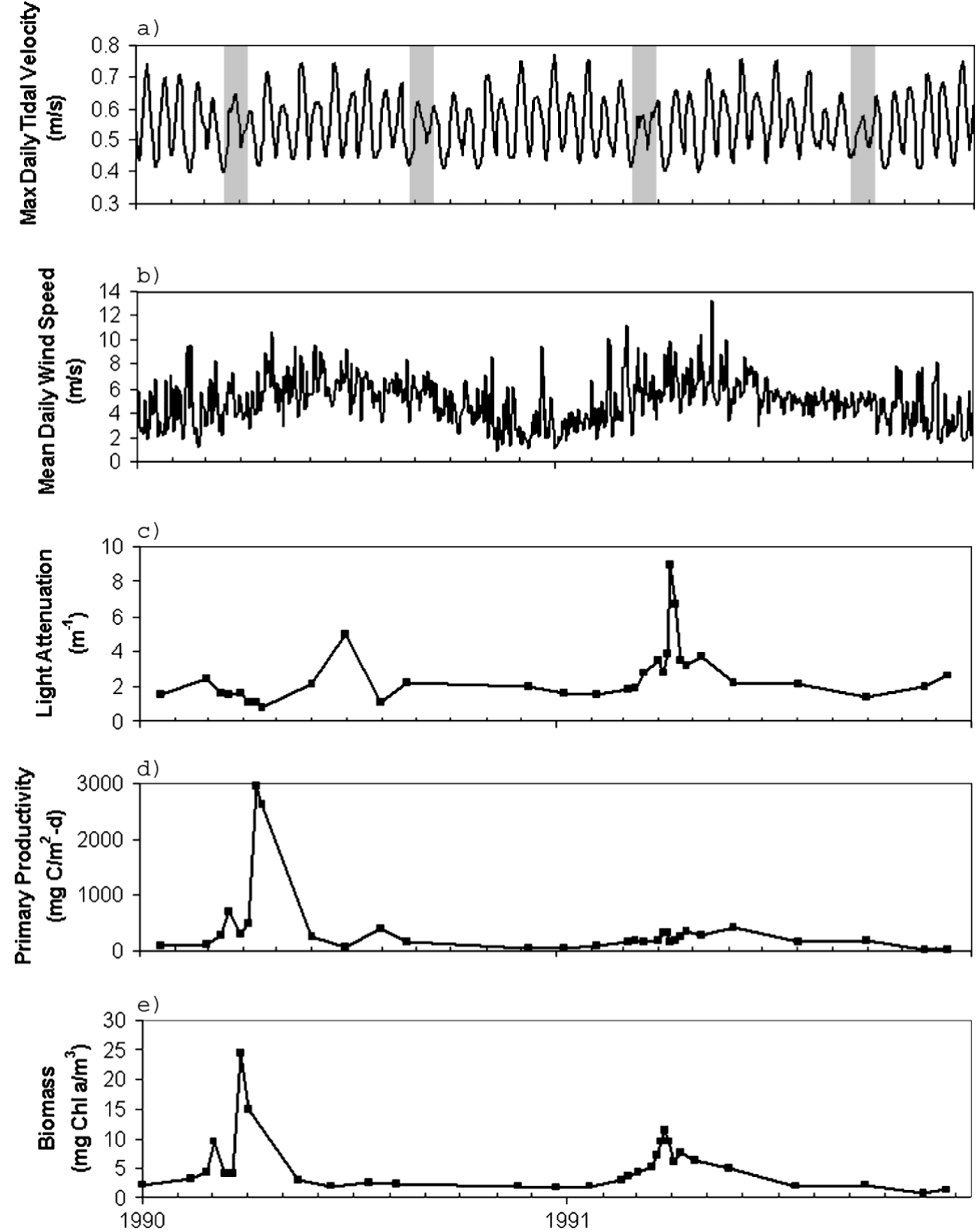

Fig. 3. Dry year measurements in South San Francisco Bay (SSFB; 1990 and 1991). Time series of: (a) maximum daily tidal velocity (Foreman 1978), gray bands are the critical periods; (b) mean daily wind speed (National Climate Data Center, available at lwf.ncdc.noaa.gov/oa/ ncdc.html); (c) light attenuation; (d) primary productivity (calculated from measured light attenuation and chlorophyll a [Cole \& Cloern 1987]; and (e) phytoplankton biomass from Stn 27 (channel) in SSFB (see Fig. 2). Source available at sfbay.wr.usgs. gov/access/wqdata/ wind magnitude, phasing, and fetch). Ultimately we encapsulated these processes into simple parameterizations.

We modeled turbidity and thereby, light availability, as a function of SSC, phytoplankton biomass, detritus, and dissolved organic matter and color components (Di Toro 1978, McPherson \& Miller 1994). In this study, we focused on bloom initiation, when phytoplankton biomass is not a significant source of turbidity and the detrital component is small. Short timescale variations in SSC can cause a 3- to 10-fold variation in light attenuation $\left(k_{t}\right)$ (Vant 1990) and can account for over half of the light attenuation coefficient in the range of 1 to
$4 \mathrm{~m}^{-1}$, when bloom initiation typically occurs (Di Toro 1978, Varela et al. 1998).

Model description. The numerical model allows us to examine both the role of local processes (occurring in the vertical dimension at a point in horizontal space) and horizontal transport in phytoplankton bloom dynamics. The model consists of 2 coupled onedimensional (1D) domains of differing depths that exchange sediment and phytoplankton (see Fig. 4 for a schematic of the model domains). Each compartment is treated as horizontally homogeneous. Horizontal mass transport between the 2 compartments is modeled as a gradient diffusion process, with $K_{Y}$ (effective 


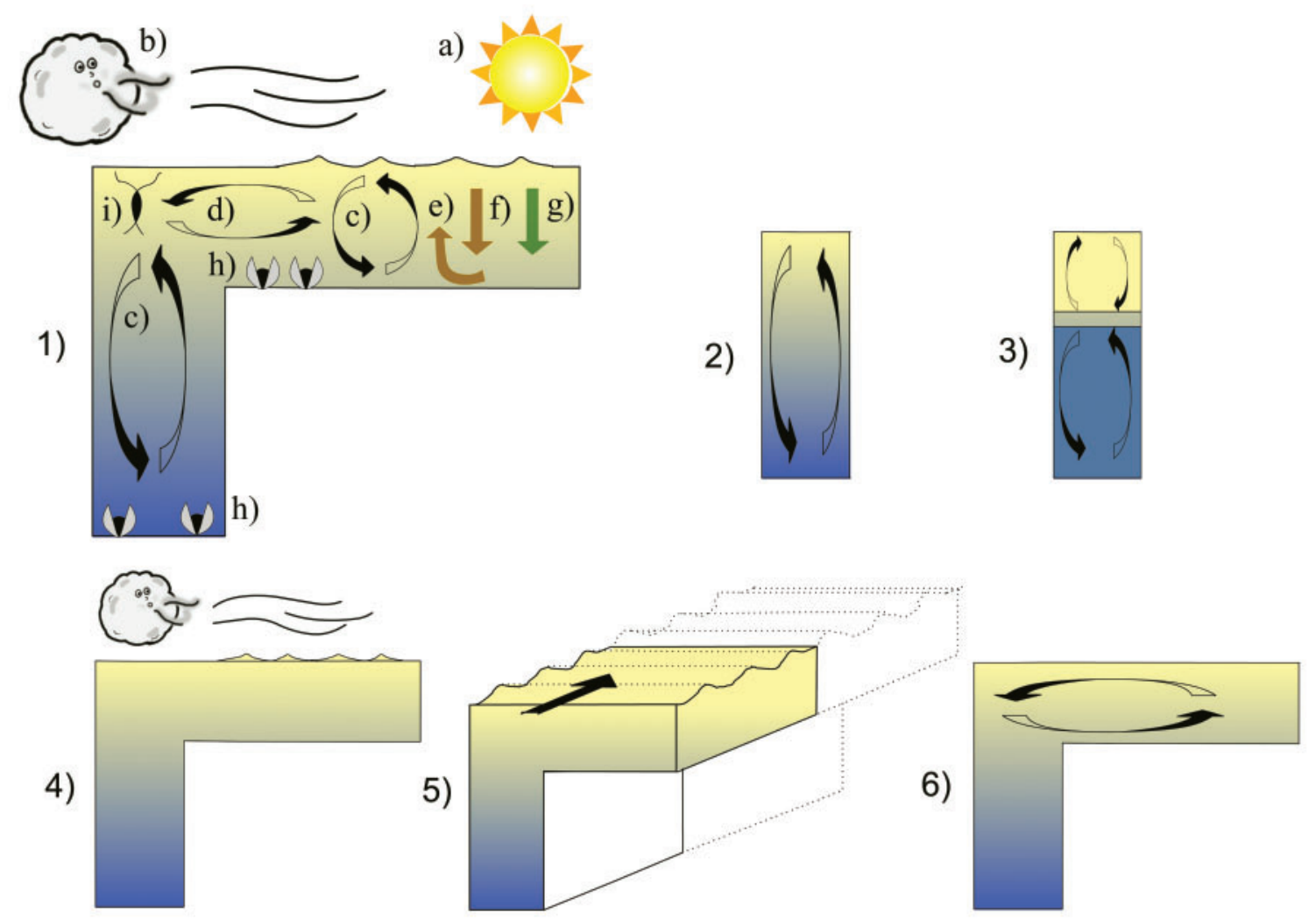

Fig. 4. Mechanisms affecting phytoplankton dynamics in a channel-shoal estuary, and experimental design. Processes: (a) lightregulated primary production (light attenuation, surface insulation), and respiration; (b) wind; (c) vertical turbulent mixing; (d) lateral transport; (e) sediment resuspension; (f) sediment sinking and deposition; (g) phytoplankton sinking; (h) benthic grazing; and (i) zooplankton grazing. Experiments: (1) base model; (2) 1D well-mixed water column; (3) 1D stratified water column; (4) $2 \mathrm{D}$ with variable wind magnitude and phasing; (5) $2 \mathrm{D}$ with varying fetch; and (6) $2 \mathrm{D}$ with varying lateral exchange

lateral diffusivity) assumed to account for all processes contributing to lateral transport. While lateral transport processes are predominantly advective, the complexity of the interaction between the numerous advective processes described by Lucas et al. (1999b) is most conveniently parameterized in a model of this type with an effective diffusivity. The $K_{Y}$ values employed in the model simulations were determined with $2 \mathrm{D}$ depth-averaged numerical simulations of conservative scalar transport in SSFB (Lucas 1997, Lucas et al. 1999b).

The scalar evolution equations (Eqs. 1 \& 5) are solved using a finite volume discretization method (MacCormack \& Paullay 1972), which employs a staggered grid that is divided into control volumes, or cells. Scalar concentrations and source/sink terms are calculated at cell centers, while all fluxes are calculated at cell faces. The finite volume approach strictly conserves mass (i.e. for a particular cell, [sources + inward fluxes] [sinks + outward fluxes] = accumulation) (Lucas 1997).

The beta method (Gross et al. 1999) was chosen for discretizing the advective (sediment sinking) terms because it can handle numerical challenges arising from having variable and often large sediment sinking rates due to aggregation and disaggregation of sediment particles. The beta method maintains numerical stability, without adding unnecessary numerical diffusion. The vertical diffusive terms in our equations are discretized using an implicit, central difference scheme.

The 1D channel and shoal compartments utilize a uniform vertical grid spacing of $0.05 \mathrm{~m}$ (i.e. 300 cells for a $15 \mathrm{~m}$ deep channel and 50 cells for a $2 \mathrm{~m}$ deep shoal). At each time step $\left(5 \times 10^{-4} \mathrm{~d}\right)$, the equations for the vertical balance of phytoplankton (photosynthesis, respiration, grazing, sinking, vertical turbulent mixing) and sediment (sinking, deposition, resuspension, vertical turbulent mixing) are solved first, and then the equations for horizontal transport are solved (i.e. the top 50 cells of the channel exchange sediment and phytoplankton biomass with the shoal). For simplicity, the water column depths remain constant throughout the simulations; however, a variable water surface height $[H(t)]$ could also effect sediment resuspension and phytoplankton growth (Grant \& Madsen 1979, Lucas \& Cloern 2002). The model is constructed in modular form: hydrodynamic, phytoplankton dynamics, and 


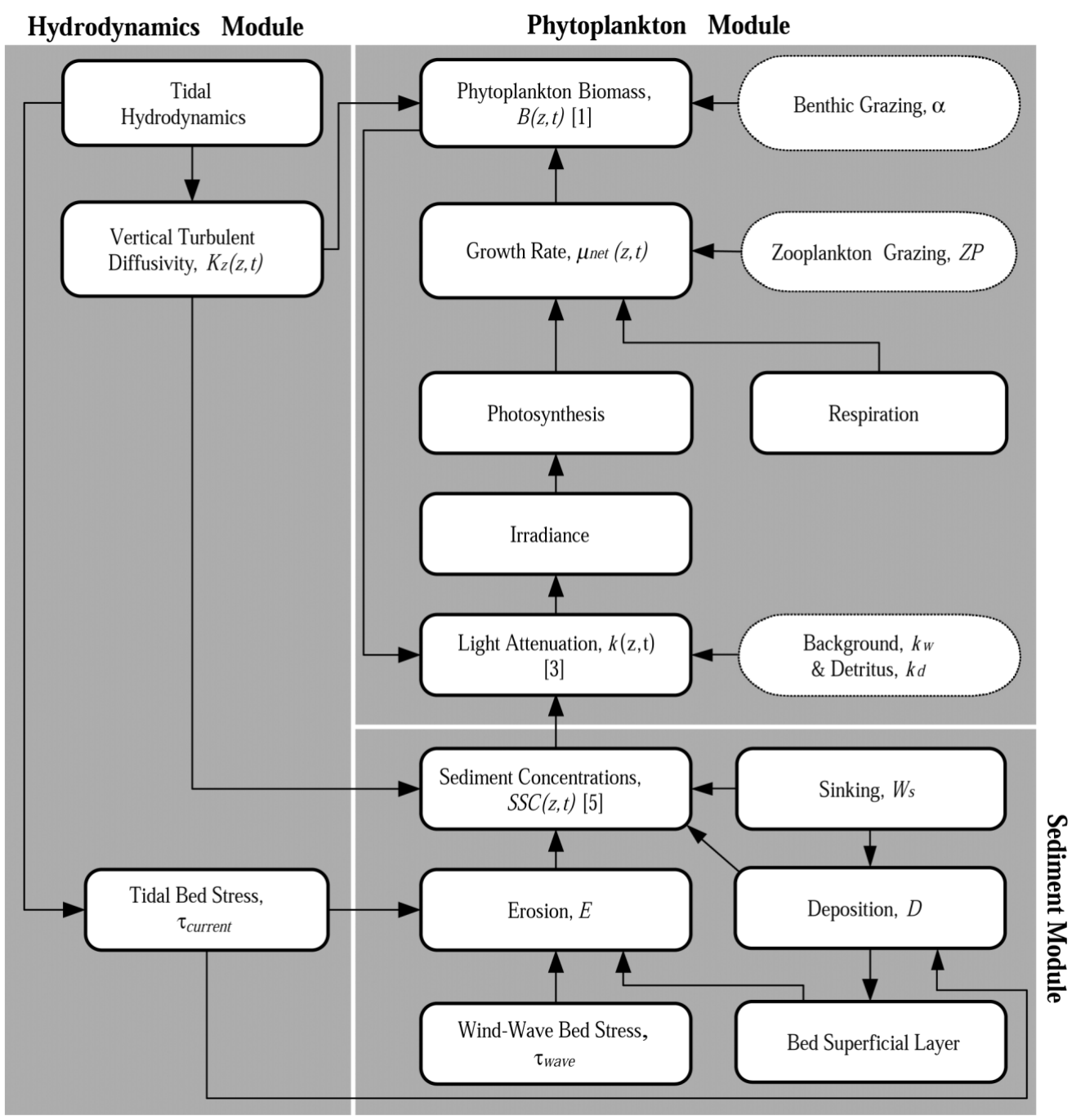

Fig. 5. 1D model structure. Numbers in brackets, correspond to the equation numbers in the module descriptions. The components in solid boxes are calculated, whereas the components in dashed boxes are specified

sediment dynamics (see Fig. 5 for a flow chart showing the relationships between the modules). The model simulations employ realistic coefficients and parameter ranges typical of SSFB (Cloern 1996).

Phytoplankton module: The output variable of the phytoplankton module is phytoplankton biomass, calculated from the time- and depth-dependent evolution equation for advective and diffusive transport, sources and sinks of phytoplankton, and the horizontal transport equation:

$$
\begin{gathered}
\frac{\partial B}{\partial t}=\mu_{\text {net }} B+\frac{\partial}{\partial z}\left(K_{z} \frac{\partial B}{\partial z}\right)-\frac{\partial}{\partial z}\left(W_{b} B\right)-\frac{\partial}{\partial z}(\alpha B) \\
\frac{\partial B}{\partial t}=\frac{\partial}{\partial y}\left(K_{y} \frac{\partial B}{\partial y}\right)
\end{gathered}
$$

Here, $B$ is the phytoplankton biomass $\left(\mathrm{mg} \mathrm{C} \mathrm{m}^{-3}\right) ; z$ is the depth $(\mathrm{m}) ; y$ is the width $(\mathrm{m}) ; \mu_{\text {net }}$ is the net rate of biomass growth $\left(\mathrm{d}^{-1}\right)$ (gross growth rate minus losses to respiration and zooplankton grazing); $K_{z}$ is the vertical turbulent diffusivity $\left(\mathrm{m}^{2} \mathrm{~d}^{-1}\right) ; K_{y}$ is the effective lateral diffusivity $\left(\mathrm{m}^{2} \mathrm{~d}^{-1}\right) ; W_{b}$ is the phytoplankton sinking rate $\left(\mathrm{m} \mathrm{d}^{-1}\right)$; and $\alpha$ is the benthic grazing rate $\left(\mathrm{m}^{3} \mathrm{~m}^{-2} \mathrm{~d}^{-1}\right)$, which is nonzero only at the bottom boundary. $K_{z}$ and $W_{b}$ are set to 0 at both the top and bottom boundaries. $\mu_{\text {net }}$ and $K_{z}$ vary with depth and time, while $W_{b}$ and $\alpha$ are assumed constant in each model run. $K_{z}$ is calculated by the 'hydrodynamic module' (described by Lucas et al. 1998), and $\mu_{\text {net }}$ is calculated as a function of the lightregulated carbon assimilation rate (Cloern et al. 1995), minus losses due to respiration and zooplankton grazing.

The local, instantaneous rate of photosynthesis (Webb et al. 1974) and photosynthetically active radiation are dependent on light availability: 


$$
k(z, t)=k_{W}+k_{b}(z, t)+k_{s}(z, t)+k_{d}
$$

where $k_{W}\left(\mathrm{~m}^{-1}\right)$ is the background light attenuation associated with water and dissolved constituents; $k_{b}$ $\left(\mathrm{m}^{-1}\right)$ is the self-shading component from phytoplankton biomass (Bannister 1974); $k_{s}\left(\mathrm{~m}^{-1}\right)$ is the component associated with suspended sediment (see below); and $k_{d}\left(\mathrm{~m}^{-1}\right)$ is the component associated with detritus.

$$
k_{S}(z, t)=M \cdot \operatorname{SSC}(z, t)
$$

where $M$ is an empirical constant $\left(=0.06 \mathrm{~m}^{2} \mathrm{~kg}^{-1} \mathrm{SSC}\right)$ from measurements made throughout San Francisco Bay during 1980 (Cloern 1987). SSC $(z, t)$, the suspended sediment concentration $\left(\mathrm{mg} \mathrm{l}^{-1}\right)$, is calculated by the 'sediment module', as described below. Table 1 contains the typical values and ranges for the biological parameters employed in our model.

Sediment module: The sediment module dynamically calculates $k_{s}$. We focused on cohesive sediments because they are the primary sediment type in the shoals of SSFB, and cohesive sediments have significantly lower sinking rates and can be maintained in the water column for a substantial length of time, thereby exerting a significant influence on turbidity. SSC is calculated using the following time- and depth-dependent evolution equation for transport, sources and sinks of sediment, and the horizontal transport equation:

$$
\begin{gathered}
\frac{\partial \mathrm{SSC}}{\partial t}=\frac{\partial}{\partial z}\left(K_{z} \frac{\partial \mathrm{SSC}}{\partial z}\right)-\frac{\partial}{\partial z}\left(\tilde{W}_{\mathrm{sed}} \mathrm{SSC}\right)+\frac{\partial}{\partial z}(E)-D \\
\frac{\partial \mathrm{SSC}}{\partial t}=\frac{\partial}{\partial y}\left(K_{y} \frac{\partial \mathrm{SSC}}{\partial y}\right)
\end{gathered}
$$

where $z$ is the depth $(\mathrm{m}) ; y$ is width $(\mathrm{m}) ; K_{z}$ is the vertical turbulent diffusivity $\left(\mathrm{m}^{2} \mathrm{~d}^{-1}\right) ; K_{y}$ is the effective lateral diffusivity $\left(\mathrm{m}^{2} \mathrm{~d}^{-1}\right) ; \tilde{W}_{\text {sed }}$ is the sediment sinking rate $\left(\mathrm{m} \mathrm{d}^{-1}\right) ; E$ is the sediment erosion rate $\left(\mathrm{kg} \mathrm{m}^{-2} \mathrm{~d}^{-1}\right)$ and $D$ is the deposition rate $\left(\mathrm{kg} \mathrm{m}^{-3} \mathrm{~s}^{-1}\right)$. $E$ and $D$ vary with time and are nonzero only at the bottom boundary. Both $K_{z}$ and $\tilde{W}_{\text {sed }}$ vary with depth and time, and are set to 0 at the top and bottom boundaries.

Deposition and erosion at the bottom boundary, and instantaneous sediment sinking rates throughout the water column, are calculated based on a cohesive sediment model developed by McDonald \& Cheng (1996). Deposition is a function of instantaneous SSC, $\tau_{\mathrm{d}}$ (critical bed shear stress for deposition $\left[\mathrm{N} \mathrm{m}^{-2}\right]$ ), and $\tau_{\text {bed }}$ (total bed shear stress produced by tidal and windwave action $\left[\mathrm{N} \mathrm{m}^{-2}\right]$ ). Erosion is a function of $P$ (erosion rate constant $\left.\left[\mathrm{kg} \mathrm{m}^{-2} \mathrm{~d}^{-1}\right]\right), \tau_{\mathrm{e}}$ (critical bed shear stress for erosion $\left[\mathrm{N} \mathrm{m}^{-2}\right]$ ) and $\tau_{\text {bed }}$.

The total bed shear stress is defined as:

$$
\tau_{\text {bed }}=\tau_{\text {current }}+\tau_{\text {wave }}
$$

where $\tau_{\text {current }}$ is the bed shear stress produced by tidal currents (calculated by the hydrodynamic module), and $\tau_{\text {wave }}$ is the bed shear stress produced by windwaves, modeled using the method of Grant \& Madsen (1979), and the shallow water wave prediction equations (USACE 1984).

The final component of the sediment module is a bed model that accounts for an easily erodible surficial layer and a more compacted underlying layer. This model has been specified to simulate realistic sediment concentrations under wind-wave resuspension scenarios. The lower critical stress associated with the surficial layer allows sediment to be deposited and eroded under tidal forcing alone. Table 2 contains the typical values and ranges for the sediment parameters employed in our model.

Hydrodynamic module: Here, the time- and depthdependent turbulent diffusivities $\left(K_{z}\right)$, and time-dependent bed shear stresses $\left(\tau_{\text {current }}\right)$ are calculated by a separate hydrodynamic code ('BGO'), an adaptation of the code of Blumberg et al. (1992). This 1D (vertical) hydrodynamic code employs the Mellor-Yamada 2.5 model for turbulence closure (Mellor \& Yamada 1982) and produces a time-depth matrix of vertical turbulent diffusivities $\left(K_{z}\right)$ and a time series of bed shear stresses $\left(\tau_{\text {current }}\right)$ for specified hydrodynamic scenarios. This model has been modified extensively for unstratified, periodically stratified (semidiurnal and sub-daily), and persistently stratified conditions under the influence of semidiurnal tidal forcing (Monismith et al. 1996, Lucas et al. 1998). Stratification scenarios are generated for the channel, and the shoal is assumed to be unstratified for all model runs. The diffusivity matrices for each compartment (channel and shoal) are read into the phytoplankton

\begin{tabular}{|c|c|c|c|}
\hline Name & Units & Value/range & Description \\
\hline$H$ & $\mathrm{~m}$ & $2-25$ & $\begin{array}{l}\text { Water column height } \\
\text { (Cloern 1996) }\end{array}$ \\
\hline$W_{b}$ & $\mathrm{~m} \mathrm{~d}^{-1}$ & 0.5 & $\begin{array}{l}\text { Phytoplankton sinking rate } \\
\text { (Cloern 1991) }\end{array}$ \\
\hline$Z P$ & $d^{-1}$ & 0.1 & $\begin{array}{l}\text { Zooplankton grazing rate } \\
\text { (Cloern 1982) }\end{array}$ \\
\hline$\alpha$ & $\mathrm{m}^{3} \mathrm{~m}^{-2} \mathrm{~d}^{-1}$ & $0-10$ & $\begin{array}{l}\text { Benthic grazing rate } \\
\text { (Thompson 1999) }\end{array}$ \\
\hline$k_{W}$ & $\mathrm{~m}^{-1}$ & $0.01-0.06$ & $\begin{array}{l}\text { Background light attenua- } \\
\text { tion of water (Di Toro 1978) }\end{array}$ \\
\hline$k_{d}$ & $\mathrm{~m}^{-1}$ & $1-10$ or $>$ & $\begin{array}{l}\text { Light attenuation from } \\
\text { detrital matter (McPherson } \\
\text { \& Miller 1994) }\end{array}$ \\
\hline$M$ & $\mathrm{~m}^{2} \mathrm{~kg}^{-1} \mathrm{SSC}$ & 0.06 & $\begin{array}{l}\text { Light attenuation from } \\
\text { suspended sediment } \\
\text { (Cloern 1987) }\end{array}$ \\
\hline
\end{tabular}
and sediment modules and used to calculate vertical turbulent fluxes of sediment and phytoplankton; the time series of tidal bed shear stresses $\left(\tau_{\text {current }}\right)$ is com-

Table 1. Typical values for all biological parameters 
Table 2. Typical ranges for all sediment parameters (Krone 1962, McDonald \& Cheng 1996)

\begin{tabular}{|lccl|}
\hline Name & Units & Value/range & Description \\
\hline$W_{\text {sed }}$ & $\mathrm{m} \mathrm{s}^{-1}$ & $0.0001-0.01$ & $\begin{array}{l}\text { Sediment sinking rate } \\
\text { at low concentrations }\end{array}$ \\
$P$ & $\mathrm{~kg} \mathrm{~m}^{-2} \mathrm{~d}^{-1}$ & $0.01-1.0$ & $\begin{array}{l}\text { Erodability } \\
\tau_{\mathrm{e}}\end{array} \mathrm{N} \mathrm{m}^{-2}$ \\
$\tau_{\mathrm{d}}$ & $\mathrm{N} \mathrm{m}^{-2}$ & $0.05-0.6$ & $\begin{array}{l}\text { Critical stress for erosion } \\
\text { Critical stress for } \\
\text { deposition }\end{array}$ \\
\hline
\end{tabular}

bined with wind wave stresses ( $\left.\tau_{\text {wave }}\right)$ to calculate deposition and resuspension of suspended sediment.

The $K_{Z}$ matrices for the stratification scenarios are generated by specifying a longitudinal salinity gradient $(\partial S / \partial x)$, maximum daily current speed $\left(U_{\max }\right)$ and mean water column depth $(H)$. The M2 tidal constituent is included in the model, and the spring-neap cycle is modeled by specifying $U_{\text {max }}$ over a $14 \mathrm{~d}$ period. The longitudinal salinity gradient, in conjunction with the sheared tidal current fluctuating on a semidiurnal timescale provides a mechanism by which an estuarine water column may stratify and destratify over the course of one tidal cycle (Simpson et al. 1990). In addition, a strong longitudinal salinity gradient can drive gravitational circulation, and if turbulent mixing is relatively weak, create persistent stratification (subdaily or longer). An initial vertical salinity distribution (typically 0) is specified, and the hydrodynamic model is 'spun up' for approximately $7 \mathrm{~d}$ (14 tidal cycles), so that stratification evolves before model output is generated for inclusion in the biological and sediment modules. See Table 3 for the hydrodynamic scenarios used in the model simulations.

Parameterization of variability. We developed 2 new parameters that capture variability in turbidity due to multiple factors (i.e. sediment sinking rates, erodability, critical shear stress for erosion, stratification, water column depths, and wind magnitude, phasing, and fetch): $V_{T}\left(\mathrm{~d}^{-1}\right)$, an index of vertical SSC clearing rate; and $H_{T}\left[\mathrm{~d}^{-1}\right]$, an index of horizontal SSC clearing rate. Because light conditions in the shoal compartment determine whether or not a system-wide bloom can occur (Lucas 1997, Lucas et al. unpubl.), in our analysis $V_{T}$ always refers to the clearing rate for the shoal.

$$
\begin{gathered}
V_{T}=\frac{\tau_{\mathrm{e}} W_{s}^{2} \rho_{s}}{u_{\text {bottom }}^{2} P H \rho_{W}} \\
H_{T}=\frac{K_{Y}}{L^{2}}
\end{gathered}
$$

where $H$ is the depth of shoal (m); $L$ is half the width of estuary $(\mathrm{m})_{i} \rho_{s}$ is density of sediment $\left(\mathrm{kg} \mathrm{m}^{-3}\right) ; \rho_{W}$ is
Table 3. Hydrodynamic scenarios

\begin{tabular}{|lccccc|}
\hline $\begin{array}{c}\text { Case } \\
\text { ment }\end{array}$ & $\begin{array}{c}U_{\max } \\
\left(\mathrm{m} \mathrm{s}^{-1}\right)\end{array}$ & $\begin{array}{c}\partial S / \partial x \\
\left(\mathrm{psu} \mathrm{km}{ }^{-1}\right)\end{array}$ & $\begin{array}{c}H \\
(\mathrm{~m})\end{array}$ & $\begin{array}{c}\text { Stratification } \\
\text { behavior }\end{array}$ \\
\hline 1 & Channel & 0.60 & 0.000 & 15 & Semidiurnal \\
2 & Channel & 0.75 & 0.196 & 15 & Sub-daily \\
3 & Channel & 0.60 & 0.261 & 15 & $\begin{array}{c}\text { Persistent } \\
\text { None }\end{array}$ \\
4 & Shoal & 0.30 & 0.000 & 2 & \\
\hline
\end{tabular}

density of water $\left(\mathrm{kg} \mathrm{m}^{-3}\right)$; and $u_{\text {bottom }}$ is a parameterization of the total velocity at the shoal bed $\left(\mathrm{m} \mathrm{s}^{-1}\right)$.

$$
u_{\text {bottom }}=\left(\frac{u_{\text {wave min }}}{u_{\text {wave max }}}\right)^{0.5}\left(u_{\text {wave average }}+u_{\text {current }}\right)
$$

where $u_{\text {wave average }}$ is the time-averaged wave-generated orbital velocity at the bed $\left(\mathrm{m} \mathrm{s}^{-1}\right) ; u_{\text {current }}$ is the average bottom tidal velocity over a spring-neap tidal cycle $\left(\mathrm{m} \mathrm{s}^{-1}\right) ; u_{\text {wave min }}$ and $u_{\text {wave max }}\left(\mathrm{m} \mathrm{s}^{-1}\right)$ are the minimum and maximum wave-generated maximum orbital velocity over a specified time period (i.e. day, week, springneap cycle), respectively. The sum of $u_{\text {wave average }}$ and $u_{\text {current }}$ approximates the total bottom shear velocity, while $u_{\text {wave min }} / u_{\text {wave max }}$ allows us to discriminate between constant flows, flows with constant wind conditions, and flows with temporal wind variability.

$V_{T}$ is an index of the net rate of sediment clearing in the vertical dimension (removal relative to erosion), where the numerator contains the mechanisms for decreasing turbidity, and the denominator contains the mechanisms for increasing turbidity. As $V_{T}$ increases, the water column clears more rapidly due to vertical transport processes. A high value of $V_{T}$ represents a water column that is clear, while a low value represents a turbid water column. For example, if sediment sinking $\left(W_{s}\right)$ is increased then $V_{T}$ is increased, and the water column clears faster.

As $u_{\text {bottom }}$ increases, more sediment is eroded and $V_{T}$ decreases. In this case, it is useful to look at both parts of $u_{\text {bottom }}$ separately because it is important to consider both the mean magnitude of the wind and its temporal variability. As the average magnitude of the wind and the average total bed shear velocity increase, $u_{\text {wave average }}+$ $u_{\text {current }}$ increases. However, 2 different wind scenarios can have the same average magnitude and therefore, the same average bed shear velocity, but suspend differing amounts of sediments because of daily or subdaily variations in wind amplitude. Therefore, the deviation around the average $\left(u_{\text {wave } \min } / u_{\text {wave max }}\right)$ must also be accounted for. As $u_{\text {wave min }} / u_{\text {wave max }}$ approaches 1 , the temporal variability decreases (approaching a constant wind velocity). On the other hand, if $u_{\text {wave min }} / u_{\text {wave max }}$ is very small, the wind is highly variable over time. The combination of $u_{\text {wave average }}+u_{\text {current }}$ (magnitude) and $u_{\text {wave min }} / u_{\text {wave max }}$ (variability) determines if net de- 
position or net resuspension occurs over a specific time period. If the average wind magnitude is large and the variability ratio approaches 1 , net resuspension will likely occur; if the average wind magnitude is small and the variability ratio approaches 1 , net deposition will likely occur. As variability in the wind increases, $u_{\text {wave } \min } / u_{\text {wave max }}$ decreases, and so does the potential for continuously maintaining sediment in suspension.

$H_{T}$ is an index of the net rate of horizontal sediment clearing. As $K_{Y}$ and thereby, $H_{T}$, increases, the potential for transporting sediment from the shoal to the channel is increased. As $L$ increases, the length over which sediment must be transported from the shoal to the channel increases; therefore, the transfer rate (and $H_{T}$ ) decreases.

\section{RESULTS}

\section{Temporal variability}

Spring-neap variability

We first explored vertical $k_{t}$ variability with the model in 1D mode $\left(K_{Y}=0\right)$. We focused on the deep channel where wind-wave sediment resuspension is negligible and the effect of stratification on turbidity could be isolated. The model was run 2 ways: with $k_{t}$ varying as a function of SSC, and with $k_{t}$ constant in both depth and time. For the constant value, we chose the time-averaged $k_{t}$ for the top (surface) cell calculated from the variable $k_{t}$ simulation, which produced an upper estimate of the time-averaged light environment encountered by phytoplankton in the water column. Reduced growth occurs in this case because the constant value of $k_{t}$ does not allow for periods of increased growth (enhanced light penetration) during the less energetic neap tides when the water column clears. Stratification amplifies the spring-neap variability in turbidity. A bloom can develop during neap tide due to net sediment deposition when the water column is stratified.

\section{Wind magnitude and phasing}

To explore the effects of wind magnitude and phasing with the tides and diel light cycle on sediment and phytoplankton dynamics, we used the model in 2D mode with $K_{Y}=25 \mathrm{~m}^{2} \mathrm{~s}^{-1}$. Fig. 6 shows calculated depth-averaged biomass and SSC for 3 wind scenarios and a channel-shoal system with semidiurnal stratification in the channel (Cases 1 and 4, Table 3). Fig. 6a depicts a situation in which there is no wind. In this case, little sediment is resuspended because bed shear stresses produced by tidal forcing alone do not resuspend much sediment $\left(\tau_{\text {bed }} \leq \tau_{\mathrm{e}}\right)$; therefore, SSC remains low and phytoplankton biomass increases in both the channel and shoal. However, the majority of growth occurs in the shoal and phytoplankton biomass is transported to the channel.

Fig. $6 \mathrm{~b}$ illustrates the case of a daily wind cycle with a peak wind of $6.5 \mathrm{~m} \mathrm{~s}^{-1}$ at 15:00 h (the spring/summer sea breeze typical over SSFB). For part of the daily cycle, $\tau_{\text {bed }}$ is greater than $\tau_{\mathrm{e}}$ and sediment is resuspended; while for other parts of the cycle, $\tau_{\text {bed }}$ is less than $\tau_{\mathrm{d}}$ and sediment is deposited. During neap tide, sediment deposition and resuspension are nearly in balance. During spring tide when tidal currents are stronger, $\tau_{\text {bed }}$ is larger (due to significant $\tau_{\text {current }}$ contribution), resuspension exceeds deposition and sediment accumulates in the water column. Sediment is also transported to the channel from the shoal where wind-wave resuspension occurs (larger $\tau_{\text {wave }}$ ), and SSC in the channel reaches a peak near the end of spring tide, causing decreased phytoplankton growth. Phytoplankton growth is maximized when the sediment fluctuations caused by the daily wind cycle produce a fairly clear water column for part of the day. The timing of the peak wind also affects phytoplankton growth. If the daily peak surface irradiance coincides with the daily turbidity minimum, growth is greater than if it coincides with the daily turbidity maximum.

Fig. 6c illustrates a case with constant wind equal to $6 \mathrm{~m} \mathrm{~s}^{-1}$. In this scenario, deposition and resuspension are balanced throughout the day (sediment is constantly resuspended since $\tau_{\text {wave }}$ is constant and therefore, $\tau_{\text {bed }}>\tau_{\mathrm{e}}$ ), and SSC remains nearly constant in the channel and the shoal throughout the simulation. No phytoplankton growth occurs during this simulation because there are no periods of water column clearance. This represents a case with minimal tidal variability in the shoal water column depth. Significant water column depth variability in the shoal, due to tidal shallowing and deepening, would produce enhanced wind-wave resuspension when the water column is shallower, and decreased resuspension when the water column is deeper.

\section{Spatial variability}

\section{Fetch}

In addition to regulating the temporal and vertical variability of SSC, wind also influences the horizontal distribution of suspended sediment through a 'fetch effect'. A greater fetch is associated with larger windwaves and therefore, increased sediment resuspension. This is illustrated in Fig. 7, in which 3 nearly iden- 
a)
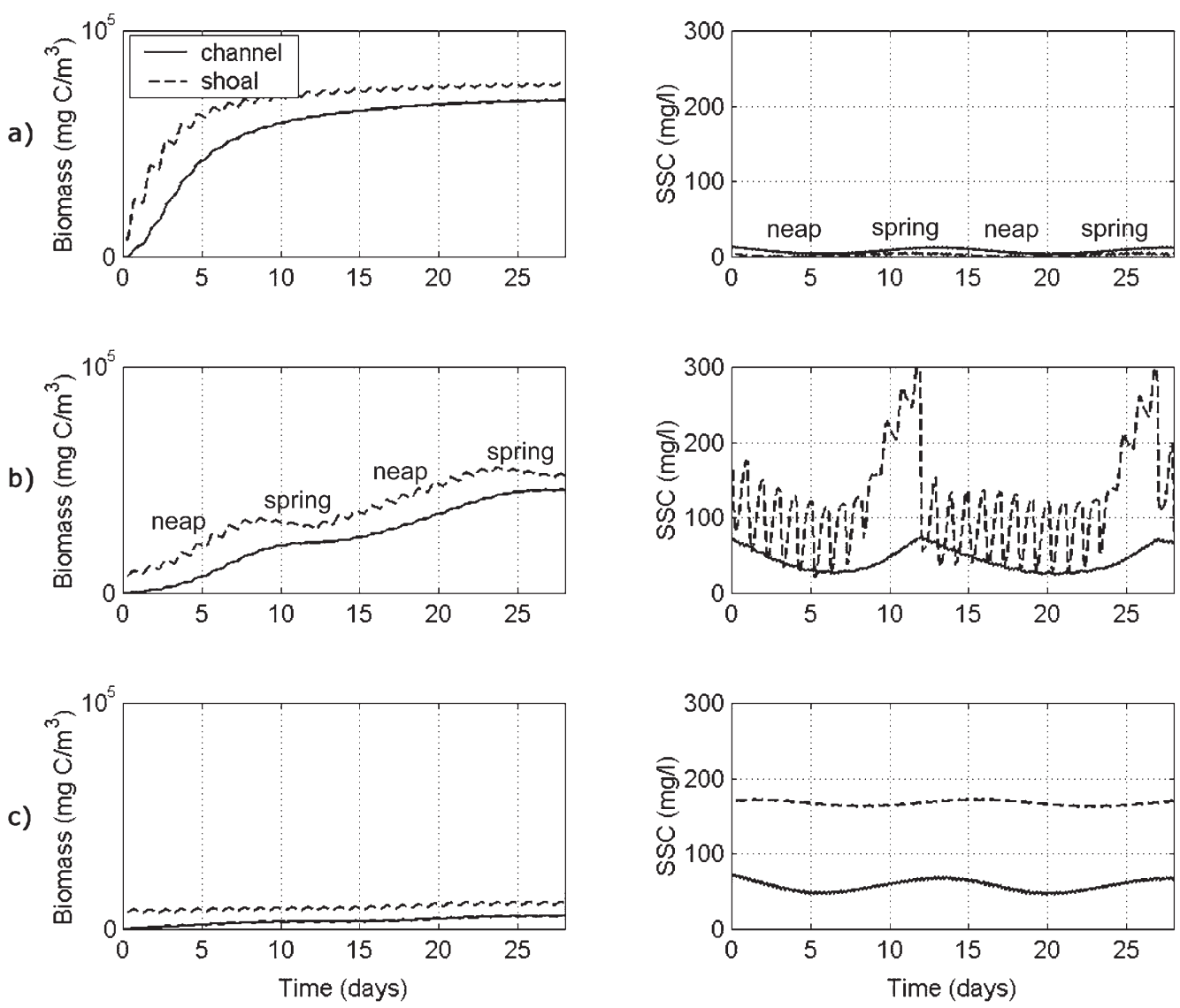

Fig. 6. Effect of wind variability on depth-averaged suspended sediment concentrations (SSC) and phytoplankton biomass for semidiurnal stratification (Case 1). (a) No wind, (b) diurnal wind (3.5 to $6.5 \mathrm{~m} \mathrm{~s}^{-1}$; fetch $\left.=14 \mathrm{~km}\right)$, (c) constant wind $\left(6 \mathrm{~m} \mathrm{~s}{ }^{-1}\right.$; fetch $=14 \mathrm{~km}$ )

tical model runs with semidiurnal stratification (Cases 1 and 4, Table 3), and a constant $6 \mathrm{~m} \mathrm{~s}^{-1}$ wind are shown, and only fetch was varied. In Fig. $7 \mathrm{a}$, the fetch is $10 \mathrm{~km}$ and SSC remains low enough for phytoplankton growth to occur. In Fig. 7b, the fetch is $14 \mathrm{~km}$ and sediment concentrations are higher, allowing only minimal phytoplankton growth. When the fetch is increased to $18 \mathrm{~km}$ (Fig. 7c), the water column becomes too turbid for phytoplankton to grow. As fetch is increased, turbidity in the shoal increases. This increase in turbidity is primarily responsible for the muted bloom in Fig. $7 \mathrm{~b}$ and the phytoplankton biomass decline in Fig. $7 \mathrm{c}$.

\section{Lateral transport}

Lateral transport regulates the relative balances of both SSC and phytoplankton in the channel and the shoal. Net sediment transport is typically from the turbid shoal to the channel, providing a sediment sink that reduces the severity of light limitation in the shal- lows so that phytoplankton growth can occur. Fig. 8 depicts a model scenario with semidiurnal stratification (Cases 1 and 4, Table 3) and varying lateral exchange conditions. In Fig. 8a, net sediment transport is to the channel, improving light .conditions in the shoal for phytoplankton growth. Phytoplankton biomass is also transported from the shoal to the channel, so that biomass increases in both compartments. Fig. 8b depicts the same scenario, but with slower lateral exchange. In this case, sufficient sediment is transported to the surface layer of the channel to inhibit a channel bloom; however, the amount of sediment transported from the shoal is inadequate to significantly reduce the turbidity.

\section{Exploration of $V_{T}-H_{T}$ parameterization}

For each of the 750 model simulations, we calculated $V_{T}$ and $H_{T}$ and recorded the phytoplankton population response. The responses were categorized into 5 basic potential outcomes: (1) system-wide death, where bio- 

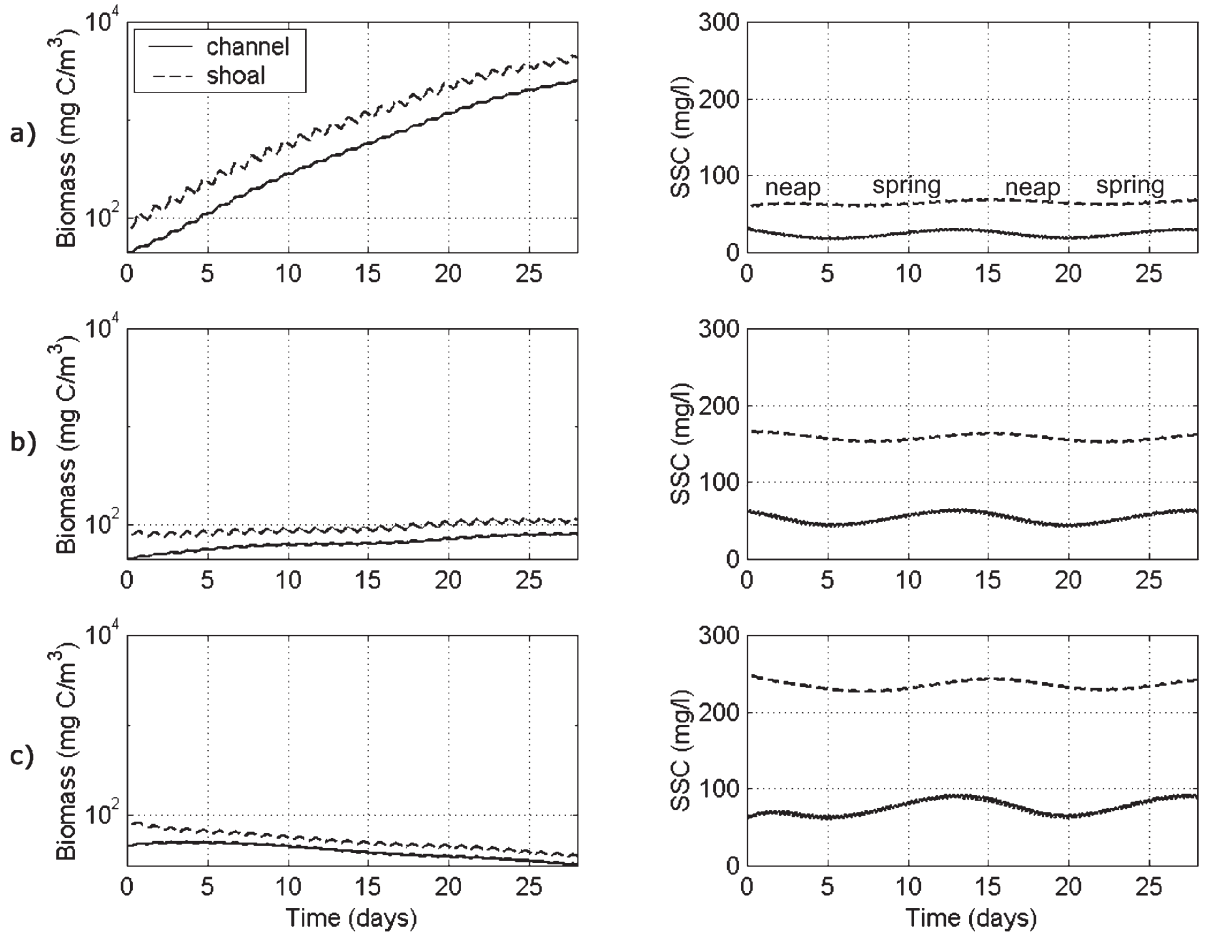

Fig. 7. Effect of increasing fetch on depth-averaged suspended sediment concentrations (SSC) and phytoplankton biomass for semidiurnal stratification (Case 1). (a) Fetch $=10 \mathrm{~km}$, (b) fetch $=14 \mathrm{~km}$, (c) fetch $=18 \mathrm{~km}$

mass declines in both the channel and shoal; (2) locally supported channel bloom, where growth occurs only in the channel; (3) channel supported system-wide bloom, where growth occurs primarily in the channel, and horizontal transport allows biomass to increase in both the channel and the shoal; (4) system-wide shoal supported bloom, where growth occurs primarily in the shoal, and horizontal transport allows biomass to increase in both the channel and the shoal; and (5) locally supported shoal bloom, where growth occurs only in the shoal.

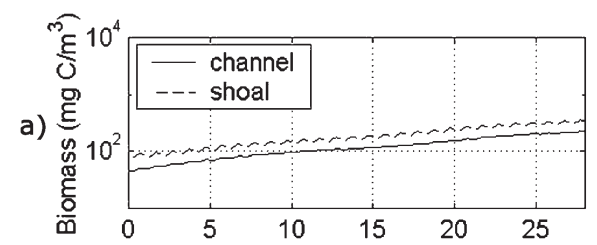

b)

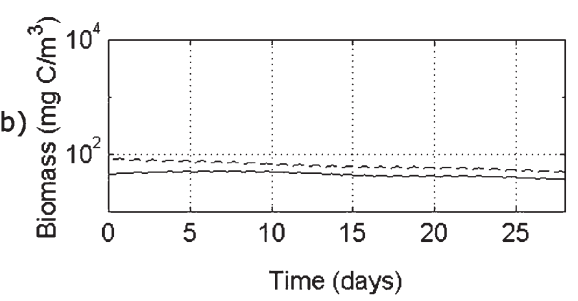

Fig. 9 shows the $V_{T}-H_{T}$ plane for 3 stratification scenarios: semidiurnal, sub-daily and persistent. The 5 outcome categories are represented by regions on the $V_{T}-H_{T}$ plane (only 4 of the 5 regions are depicted on Fig. 9). Similarities are evident between the 3 plots. The regions have the same general relationships with each other, although the relative size and location of each region shifts as the degree of stratification is intensified. As stratification increases from semidiurnal to persistent (moving from Fig. 9a to c), Regions 2 and 3 (local and system-wide channel-supported
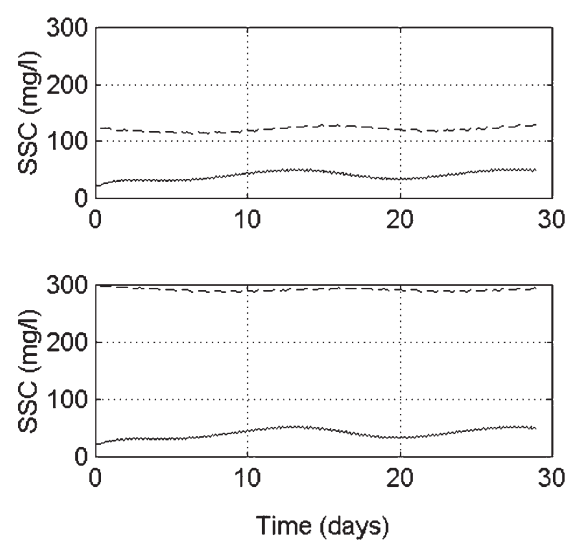

Fig. 8. Effect of increasing horizontal exchange on depth-averaged suspended sediment concentrations (SSC) and phytoplankton biomass for semidiurnal stratification (Case 1). (a) $K_{\mathrm{y}}=35 \mathrm{~m}^{2} \mathrm{~s}^{-1}$, (b) $K_{\mathrm{y}}=11.5 \mathrm{~m}^{2} \mathrm{~s}^{-1}$ 

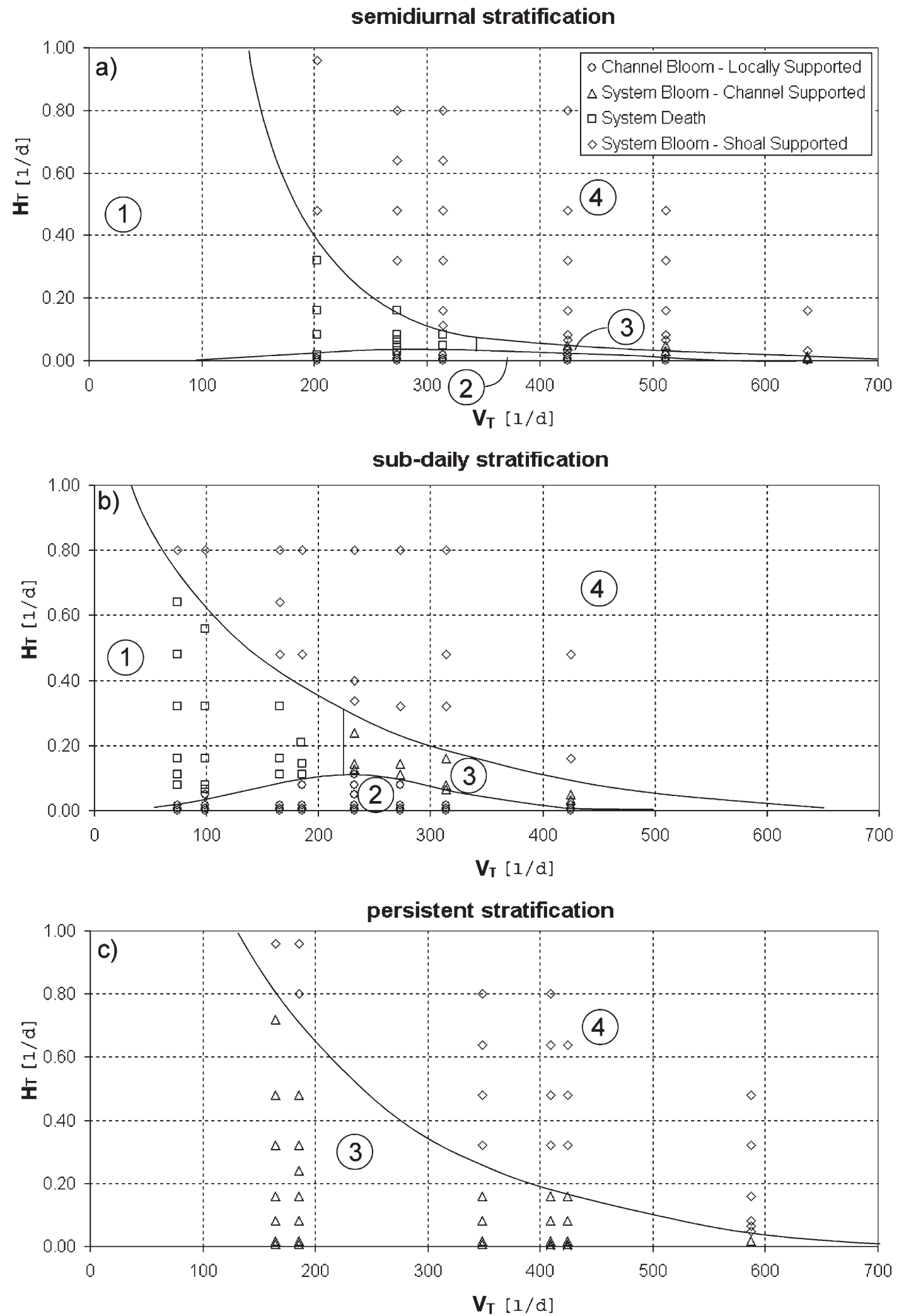

Fig. 9. $V_{T}-H_{T}$ planes for 3 cases of increasing stratification in the channel based on model simulations. (a) Semidiurnal stratification in the channel (Case 1, see Table 3); (b) sub-daily stratification in the channel (Case 2); and (c) persistent stratification in the channel (Case 3). Case 4 in the shoal for all simulations. Four outcome regions are apparent: (1) system-wide death; (2) channelsupported local bloom; (3) channel-supported system-wide bloom; and (4) shoal-supported system-wide bloom 
bloom) move to the left and expand. This is because increasing stratification in the channel creates a longer-lived, clear(er) surface layer and promotes phytoplankton growth. For a particular value of $V_{T}$ (e.g. $35 \mathrm{~d}^{-1}$ ), increasing stratification produces a wider range of $H_{T}$ for which the channel can support a local or system-wide bloom (thus, Regions 2 and 3 expand). As stratification increases, sediment concentration in the channel surface layer decreases because the surface layer is less turbulent and the sediment sinks out; therefore, the channel surface layer can maintain a bloom despite increased horizontal transport and sediment delivery from the shoal. For small $V_{T}$ (turbid shoal) and large $H_{T}$, system-wide blooms can occur because the vigorous lateral transport processes mix the clearer upper channel waters and the sedimentladen shoal waters, resulting in a net exchange of sediment to the surface waters in the channel. As a result, the sediment concentration and thereby, the turbidity in the shoal, is reduced allowing phytoplankton growth to occur. As $H_{T}$ decreases, sediment transport from the turbid shoal to the channel decreases and the system moves towards system-wide death. For small $V_{T}$ and small $H_{T}$, the system moves from systemwide death into the locally-supported channel bloom region, and finally into the channel-supported systemwide blooms when persistent stratification occurs. For large $V_{T}$ (clear shoal) and large $H_{T}$, a shoal-supported system wide bloom occurs regardless of stratification. As $H_{T}$ decreases, the system moves from a shoalsupported system-wide bloom to a channel-supported system-wide bloom.

When the channel is persistently stratified throughout the spring-neap tidal cycle, Regions 1 and 2 are pushed so far to the left they no longer exist, leaving only Regions 3 and 4 (Fig. 9c). In this case, a systemwide bloom will always occur unless the background light attenuation $\left(k_{w}\right)$ is high, but the estuary compartment (channel or shoal) primarily responsible for supporting the bloom shifts depending on $V_{T}$ and $H_{T}$. Typically, at low $V_{T}$ and $H_{T}$ (turbid shoal) the channel will support the bloom (if one occurs at all), whereas at high $V_{T}$ and high $H_{T}$ (clear shoal) the shoal will support the bloom.

Results in Fig. 9 are based on the assumption that no benthic grazing occurs in the channel or the shoal, but benthic grazing introduces another significant 'rate' to the estuarine balance for phytoplankton (Cloern 1982, Lucas et al. 1998, 1999a,b). In the absence of horizontal exchange $\left(H_{T}=0\right)$, no bloom will occur if the benthic grazing rate exceeds the phytoplankton growth rate. When horizontal exchange occurs, the phytoplankton bloom outcome is determined by the balance between rates of benthic grazing, horizontal transport, vertical sediment transport and phytoplankton growth. For a given compartment (channel or shoal), if benthic grazing exceeds growth rates plus horizontal import, no bloom occurs. If benthic consumption is less than growth plus horizontal import, a bloom occurs. The same $5 \quad V_{T^{-}} H_{T}$ outcome regions exist; however, the relative size and location of the regions shift as benthic grazing in the shoal and/or channel is increased (as compared with Fig. 9), and Region 5 (locally supported shoal bloom) appears when benthic grazing in the channel is high and the channel is not persistently stratified. The shoal is unable to support a channel bloom in Region 5 because benthic consumption of biomass in the channel exceeds the transport rate of biomass from the shoal.

\section{DISCUSSION AND CONCLUSION}

We have used a numerical model to systematically explore the effect of spatial and temporal variability in turbidity on phytoplankton dynamics. Specifically, we explored the mechanisms that affect vertical and horizontal clearing of sediment from the water column (Fig. 10). Although we have used SSFB as an example, our investigation has identified several important points of potential relevance to any shallow estuary: (1) The timing of the wind with semidiurnal tides and the spring-neap cycle can significantly enhance spring-neap variability in turbidity and phytoplankton biomass; (2) Fetch is a significant factor potentially affecting phytoplankton dynamics by enhancing and/or creating spatial variability in turbidity; (3) The combined effect of the processes influencing turbidityand thus affecting potential phytoplankton bloom development-can be parameterized with 2 indices for vertical and horizontal clearing of the water col-

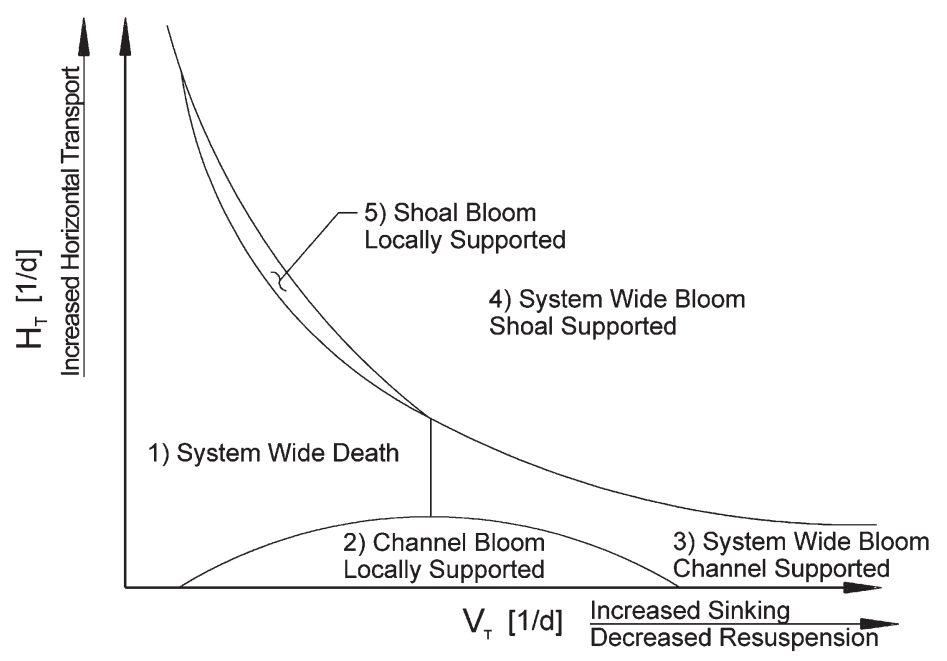

Fig. 10. Conceptual framework for phytoplankton response to horizontal and vertical clearing of the water column 
umn; and (4) tidal forcing may drive variability in turbidity over weekly (spring-neap) timescales; however, wind can be a dominant factor influencing both spatial and temporal variability in SSC, and therefore, phytoplankton dynamics. The phasing of the wind with semidiurnal tides and the spring-neap cycle can dominate spring-neap variability in turbidity. In addition, small variations in wind speed can produce big changes in phytoplankton dynamics. These changes in wind speed directly influence vertical sediment clearing of the water column $\left(V_{T}\right)$. In the absence of wind (Fig. 6a), $V_{T}$ and $H_{T}$ fall in the region of shoalsupported system-wide bloom (Region 4); whereas with a variable wind (Fig. 6b) conditions oscillate between a shoal-supported system-wide bloom (Region 4) and system-wide biomass decline (Region 1) over the spring-neap tidal cycle. In the latter case, growth occurs primarily on neap tide and decay occurs on spring tide, when the combination of the more energetic tidal currents and wind-waves produce peak SSC. A constant high wind (Fig. 6c) creates systemwide death conditions where no phytoplankton growth occurs (Region 1).

Fetch may also significantly affect phytoplankton dynamics. The fetch effect creates spatial turbidity variability (see Fig. 7), contributing to spatial variability of phytoplankton growth and biomass distribution. Areas with a shorter fetch have smaller wind-waves and therefore, lower potential for resuspending sediment, creating a less turbid water column and a higher $V_{T}$. Fig. 7a depicts a high $V_{T}$ value and a shoalsupported system-wide bloom (Region 4). As fetch is increased and thereby, $V_{T}$ is decreased, growth conditions move toward system-wide death (Region 1) (Fig. 7c). Changes in wind direction over an estuarine basin can, therefore, be as important in regulating phytoplankton dynamics as changes in wind speed.

Lateral transport is important for exchanging both phytoplankton and sediment between channel and shoal. Sediment export can reduce turbidity in the shoal, allowing phytoplankton growth to occur where otherwise it might not (see Fig. 8). For low $V_{T}$ (turbid shoal), intensifying lateral transport raises $H_{T}$ and therefore, moves growth conditions from locally supported channel bloom (Region 2), to system-wide death (Region 1), to shoal-supported system-wide bloom (Region 4). For high $V_{T}$ (clear shoal), horizontal transport of phytoplankton allows system-wide blooms to occur: as $H_{T}$ increases, growth conditions move from a locally supported channel bloom (Region 2), to a channel-supported system-wide bloom (Region 3) and ultimately, to shoal-supported system-wide bloom conditions (Region 4).

Our model results allowed us to develop a new conceptual framework for exploring phytoplankton bloom potential in channel-shoal systems with respect to horizontal and vertical clearing of the shoal $\left(H_{T}\right.$ and $V_{T}$, respectively), consisting of the 5 response regions in $H_{T}-V_{T}$ space (Fig. 10). Although the relative size and location of the regions shift as factors, such as the degree of stratification in the channel (Fig. 9), and benthic grazing rates in the channel and shoal are varied, the regions maintain the same general relationships.

The contrast between spring bloom dynamics in SSFB between 1990 and 1991 provides a useful test case for our conceptual framework. In this case, low wind accompanied the critical period in 1990 (between March 31 and April 7), producing low turbidity in both the shoal and the channel and creating bloom conditions (Fig. 11). High wind accompanied the same critical period in 1991 (between April 3 and 11), producing a turbid shoal where phytoplankton growth was light limited and insufficient to support a bloom in the channel (Fig. 11).

We calculated $H_{T}$ and $V_{T}$ for 3 periods during the spring bloom for each year (depicted with gray bands on Fig. 11). Because the exact sediment properties (needed to calculate $V_{T}: W_{s} \tau_{\mathrm{cr}}$ ) for SSFB were essentially unknown, we performed $56 \mathrm{~d}$ numerical simulations in order to determine them. The calibration year we used was 1990, and the sediment properties $\left(W_{s}, \tau_{\mathrm{cr}}\right)$ were used to calibrate the model and achieve a reasonable approximation of observed phytoplankton biomass magnitudes. Direct measurements in 1990, were used for the average daily wind speed, tidal forcing (Fig. 11) and benthic grazing $\left(0.1 \mathrm{~m}^{3} \mathrm{~m}^{-2} \mathrm{~d}^{-1}\right.$ in the channel and $0.5 \mathrm{~m}^{3} \mathrm{~m}^{-2} \mathrm{~d}^{-1}$ in the shoal) (J. K. Thompson pers. comm.). The sediment properties were adjusted, as part of the calibration process, within realistic ranges for SSFB (Krone 1962, McDonald \& Cheng 1996). The observations made in 1991, were used to validate our approach. The sediment properties were not changed, and measured 1991 wind speed, tidal forcing (Fig. 11) and benthic grazing $\left(0.1 \mathrm{~m}^{3} \mathrm{~m}^{-2} \mathrm{~d}^{-1}\right.$ in the channel and the shoal) (Thompson 1999) were applied. The modeled 1991 phytoplankton biomass approximated the 1991 measured phytoplankton.

The $H_{T}-V_{T}$ planes shown on Fig. 12 were developed using numerical simulations for estimated benthic grazing levels in 1990 and 1991. For our calibration year, the large bloom period in 1990 (Point $\mathrm{B}_{90}$ ) falls (as expected) in Region 4 (system-wide shoal supported bloom), as does the small bloom during the preceding neap-tide (Point $\mathrm{A}_{90}$ ). Light attenuation and chl a were not measured after April 18. However, the high winds accompanying the spring tide preceding this date imply high SSC and phytoplankton decay, therefore point $\mathrm{C}_{90}$ falls in Region 1. For our validation year, the period of high SSC (Point $\mathrm{B}_{91}$ ) in 1991, clearly falls in 

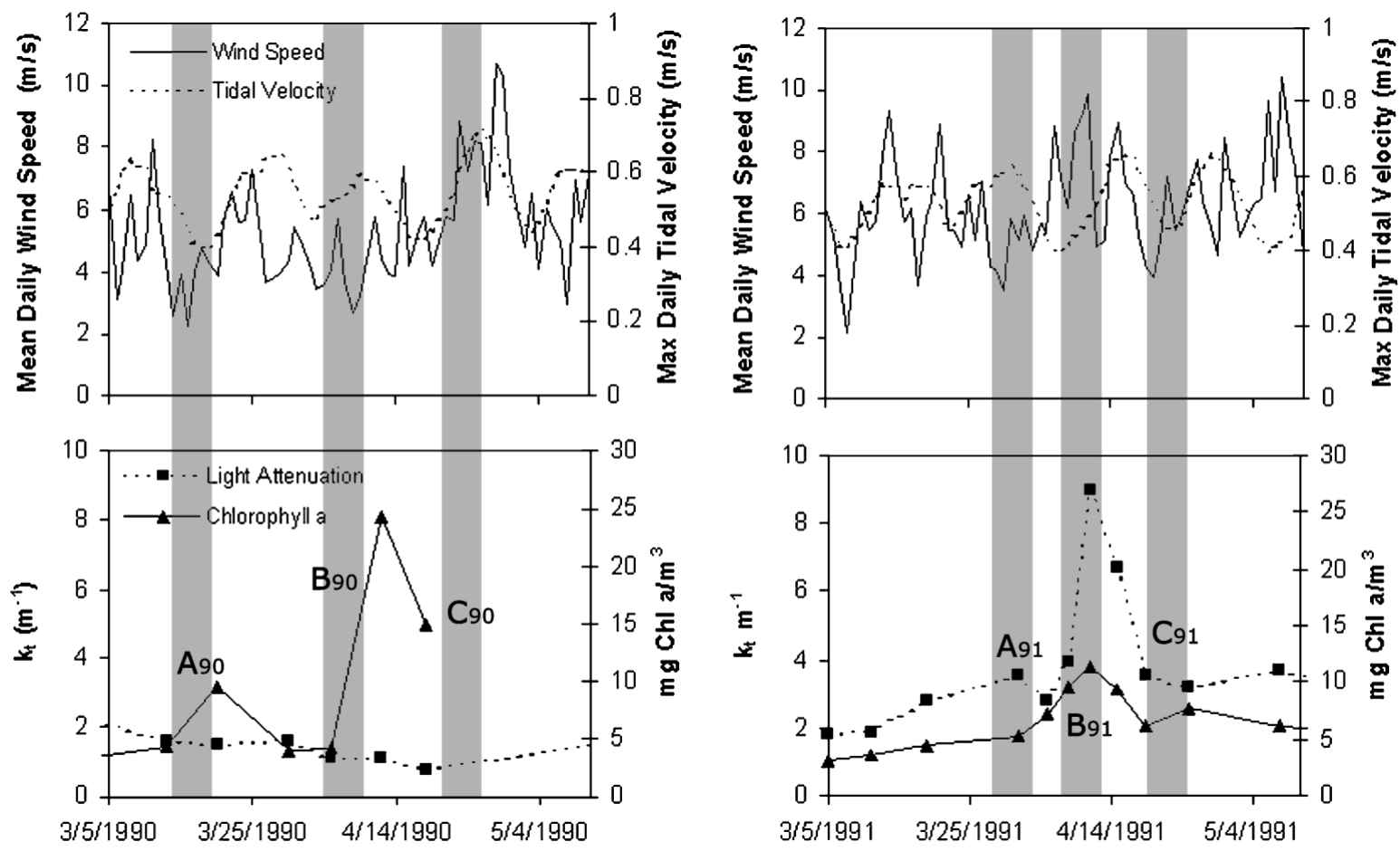

Fig. 11. Comparison of 1990 and 1991 spring bloom period light attenuation, chlorophyll a (chl a), wind speed and maximum daily tidal velocity in South San Francisco Bay (SSFB). Symbols for light attenuation and chl a indicate when data were collected at Stn 27 in SSFB (see Fig. 2). Letters $\left(A_{90}, B_{90}, C_{90}, A_{91}, B_{91}, C_{91}\right)$ correspond to Fig. 12. The gray bands represent the time periods used to calculate $V_{T}$. Source available at sfbay.wr.usgs.gov/access/wqdata/; wind data: National Climate Data Center, available at lwf.ncdc.noaa.gov/oa/ncdc.html. Dates are mo/d/yr

Region 1. Point $\mathrm{C}_{91}$ falls in the transition zone between Regions 1 and 4 ; therefore, growth was unlikely then. Point $\mathrm{A}_{91}$ falls in Region 4, and this is reflected in Fig. 11, showing that modest phytoplankton growth did occur just prior to the high wind event. Hence, the projected growth outcomes associated with different domains of $H_{T}-V_{T}$ space are indeed consistent with biomass measurements and environmental conditions observed in SSFB during the spring periods of 1990 and 1991.

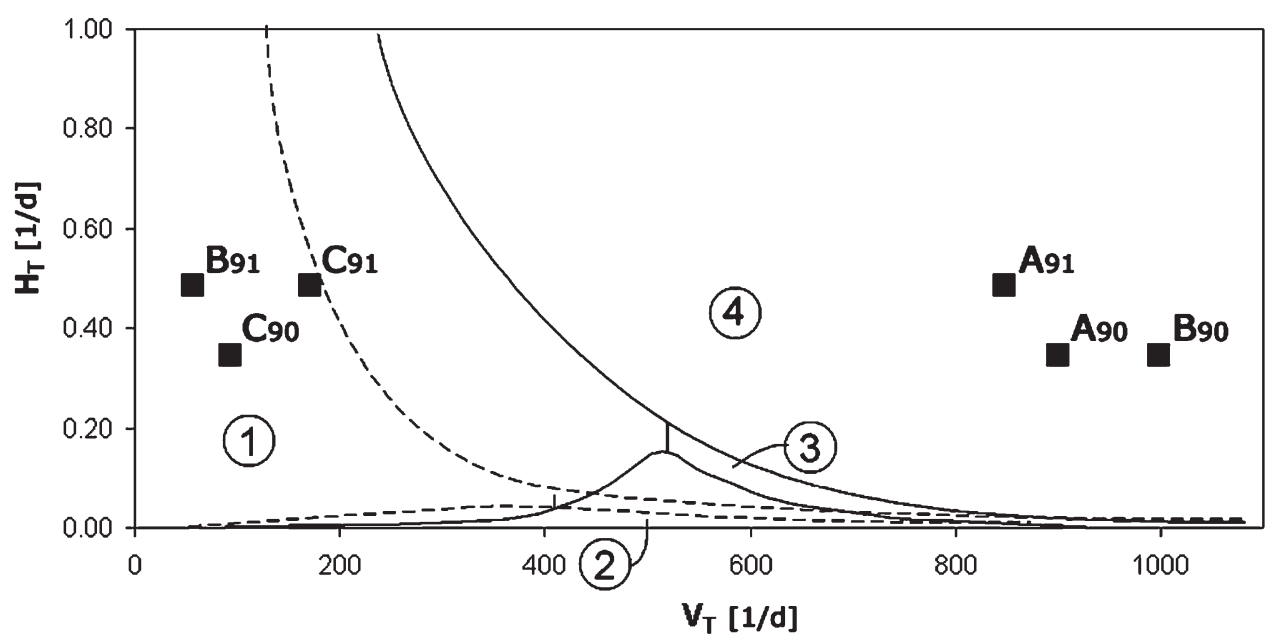

Fig. 12. $V_{T}-H_{T}$ planes based on model simulations, with data points from South San Francisco Bay (SSFB) 1990 and 1991 (corresponding to Fig. 11). Semidiurnal stratification in the channel (Case 1), and unstratified conditions in the shoal (Case 4). Dashed lines represent benthic grazing of $0.1 \mathrm{~m}^{3} \mathrm{~m}^{-2} \mathrm{~d}^{-1}$ in the channel and shoal; solid lines represent benthic grazing of $0.1 \mathrm{~m}^{3} \mathrm{~m}^{-2} \mathrm{~d}^{-1}$ in the channel and $0.5 \mathrm{~m}^{3} \mathrm{~m}^{-2} \mathrm{~d}^{-1}$ in the shoal 


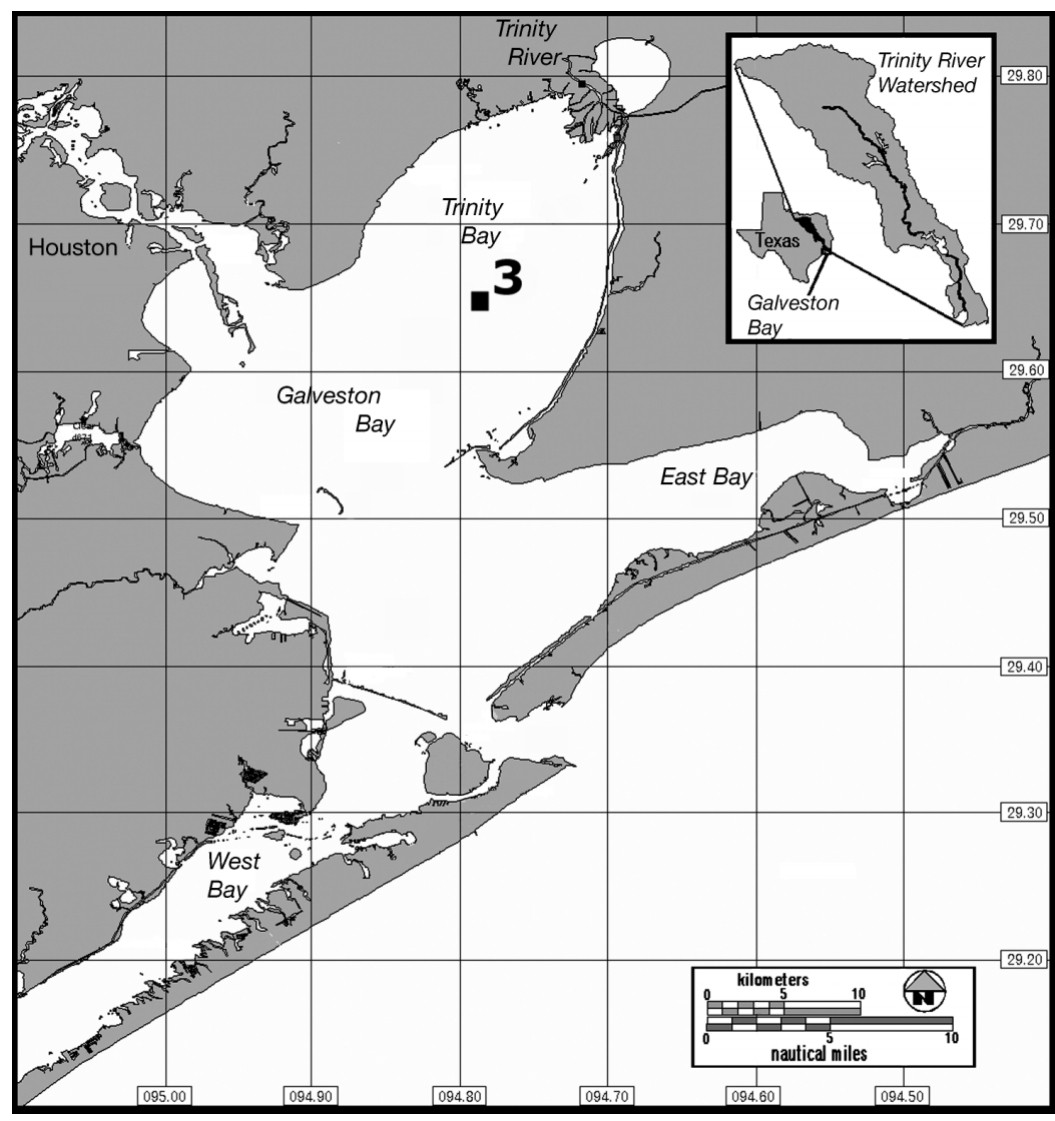

Fig. 13. Galveston Bay and location of Stn 3. Source available at www. ocean.tamu.edu/ pinckney/maps.htm

type, we expect the 5-regime map in Fig. 10 to reduce to a simpler binary 2regime relationship: a bloom develops for $V_{T}$ above some critical value (vertical sediment clearing is adequate to allow positive phytoplankton growth); no bloom develops for $V_{T}$ below that critical value (low sediment clearing results in turbid conditions).

While we do not expect the critical $V_{T}$ to be the same as that for SSFB because of distinctions between sitespecific physical and biological parameters, we do expect $V_{T}$ to effectively discriminate between conditions where blooms are likely and when they are not likely. Specifically, periods of high winds (e.g. greater than $18 \mathrm{~m} \mathrm{~s}^{-1}$ between March 7 and 15, and March 21 and 28), or moderate winds with small variability (e.g. 7.7 to $9.5 \mathrm{~m} \mathrm{~s}^{-1}$ between April 4 and 12) are associated with low $V_{T}$ values, suggesting turbid waters and negative potential phytoplankton growth. As can be seen in Fig. 14, this period of low $V_{T}$ is in fact consistent with low phytoplankton biomass (e.g. $3.5 \mathrm{mg} \mathrm{chl} \mathrm{a} \mathrm{m}{ }^{-3}$ on April 10). Furthermore, periods of low wind (e.g. 4.5 to $7 \mathrm{~m} \mathrm{~s}^{-1}$ between April 26 and May 2, and 5.9 and $7.5 \mathrm{~m} \mathrm{~s}^{-1}$ between

Our conceptual framework applies to other shallow turbid estuaries. Galveston Bay in Texas (Fig. 13) does not experience significant tidal currents, and resuspension events are almost exclusively due to wind ( $\mathrm{J}$. Pinckney pers. comm.). Even moderate winds of $8 \mathrm{~m} \mathrm{~s}^{-1}$ can stir the bottom. This system has significant benthic grazing due to oyster farming between November and January. In addition, heavy rains and fresh water inflow contribute to high dissolved inorganic nitrogen (DIN) concentrations between November and July, while DIN remains low the rest of the year (Örnólfsdóttir 2002). Because changes in benthic grazing affect the critical $V_{T}$ (the transition from phytoplankton population decay to growth), we focus here on the period between February 1 and November 1, 2001 when benthic grazing was minimal. We calculated $V_{T}$ for $7 \mathrm{~d}$ periods, using measured Galveston wind speed and tidal current data (National Ocean Service; available at co-ops.nos.noaa.gov). Since no characteristic sediment parameters were available for this system, we used the same sediment parameters as for our SSFB model runs. Because Galveston Bay is not a channel-shoal system, we treated it as a uniform shoal: the $H_{T}$ parameter is, therefore, not relevant here. Thus, for cases of this
May 9 and 16) are associated with high $V_{T}$ values, suggesting clearer waters and the likelihood of positive phytoplankton growth. Again, as seen on Fig. 14, these periods of large $V_{T}$ are in fact consistent with observations of large phytoplankton biomass in Galveston Bay

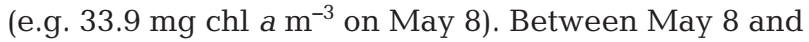
June $18, V_{T}$ was quite low over all, corresponding to an overall decrease in chl a from May 8 to June 18, due largely to periods of sustained moderate winds (May 16 to 31). June was characterized by a period of shortlived episodes of strong winds (June 1 to 8), followed by sustained low wind speeds (June 18 to 30 ) and thus, was associated with moderate to high $V_{T}$, a prediction of phytoplankton growth. Chl a in mid-June did in fact increase, but only until DIN became limiting.

We propose that spatial and temporal variability in turbidity can be expressed as 2 indices of vertical and horizontal sediment clearing rates (Fig. 10), which incorporate estuarine geometry (i.e. fetch, depth, width) and the interaction of processes operating over a range of timescales (i.e. wind, tides, sediment sinking, horizontal transport). These 2 indices capture the processes affecting turbidity that determine whether phytoplankton growth is possible, and whether a 

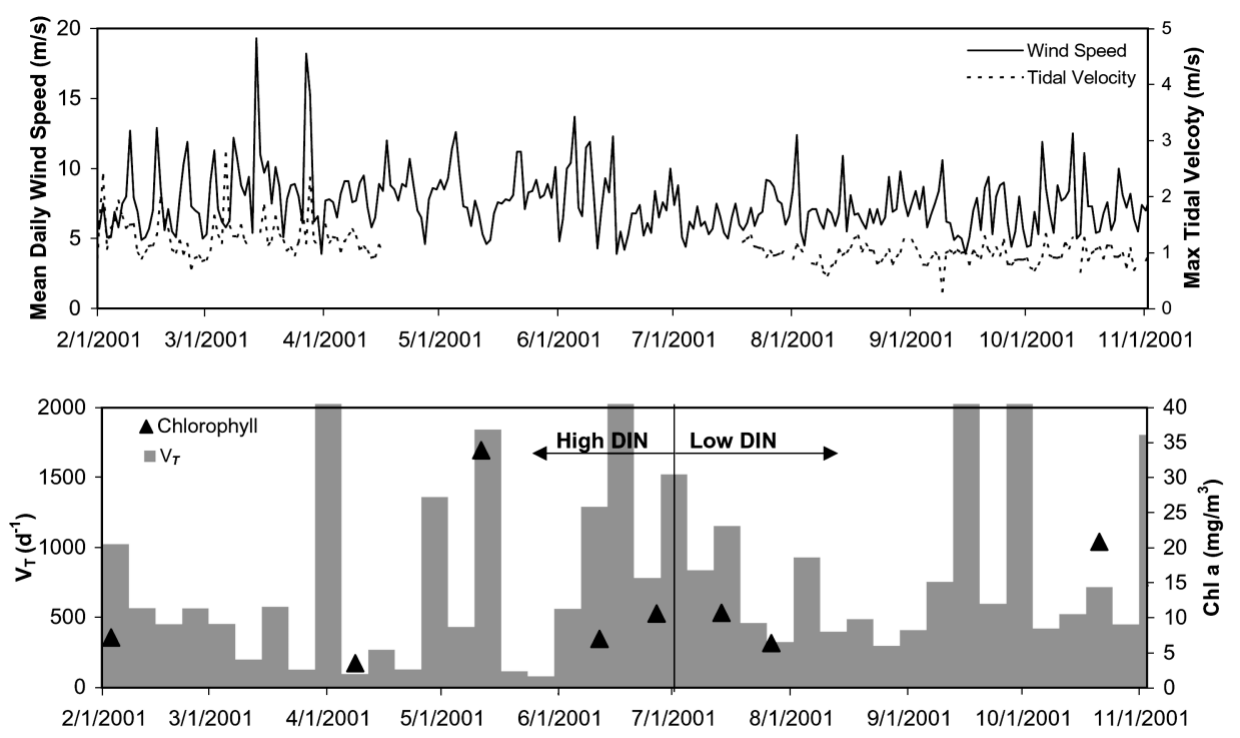

Fig. 14. Galveston Bay calculated $V_{T}$ and measured chlorophyll a (chl a), wind speed and maximum daily tidal velocity. Symbols for chl $a$ indicate when data were collected at Stn 3 (see Fig. 13). The gray bars represent $7 \mathrm{~d}$ time periods used to calculate $V_{T}$. Wind and current data: National Ocean Service; available at co-ops.nos.noaa.gov; chl a: Örnólfsdóttir (2002). Dates are mo/d/y

potential bloom is locally supported or system-wide in scale. The $V_{T}-H_{T}$ framework is a general conceptual tool for understanding the inherent system attributes affecting turbidity that can constrain phytoplankton population growth. We suggest that this tool can be applied to explore mechanistically the variability among ecosystems in their response to nutrient enrichment (eutrophication-response filter; Cloern 2001), and to guide management of individual systems by measuring the potential responses to different scenarios of nutrient loading.

Acknowledgements. This material is based upon work supported by the Cooperative State Research, Education and Extension Service, US Department of Agriculture, under Agreement No. 2001-35108-10651. We are grateful for the support of the US Department of Agriculture. Thanks to Jay Pinckney and Erla Örnólfsdóttir for providing the Galveston Bay data, and also thanks to Jan Thompson for providing benthic grazing data for South San Francisco Bay.

\section{LITERATURE CITED}

Alpine AE, Cloern JE (1988) Phytoplankton growth rates in a light-limited environment. Mar Ecol Prog Ser 44:167-173

Bannister TT (1974) A general theory of steady state phytoplankton growth in a nutrient saturated mixed layer. Limnol Oceanogr 19(1):13-30

Blumberg AF, Galperin B, O'Connor JD (1992) Modeling vertical structure of open-channel flows. J Hydraul Eng 118(8):1119-1134

Caffrey JM, Cloern JE, Grenz C (1998) Changes in production and respiration during a spring phytoplankton bloom in San Francisco Bay, California, USA: implications for net ecosystem metabolism. Mar Ecol Prog Ser 172:1-12

Cloern JE (1982) Does the benthos control phytoplankton biomass in South San Francisco Bay? Mar Ecol Prog Ser 9: 191-202

Cloern JE (1987) Turbidity as a control on phytoplankton biomass and productivity in estuaries. Cont Shelf Res 7(11-1):1367-1381

Cloern JE (1991) Tidal stirring and phytoplankton bloom dynamics in an estuary. J Mar Res 49(1):203-221

Cloern JE (1996) Phytoplankton bloom dynamics in coastal ecosystems: A review with some general lessons from sustained investigation of San Francisco Bay, California. Rev Geophys 34(2):127-168

Cloern JE (2001) Our evolving conceptual model of the coastal eutrophication problem. Mar Ecol Prog Ser 210: $223-253$

Cloern JE, Cole BE, Wong RLJ, Alpine AE (1985) Temporal dynamics of estuarine phytoplankton: a case study of San Francisco Bay. Hydrobiologia 129:153-176

Cloern JE, Grenz G, Lucas LV (1995) An empirical model of the phytoplankton chlorophyll:carbon ratio-the conversion factor between productivity and growth rate. Limnol Oceanogr 40(7):1313-1321

Cole BE, Cloern JE (1987) An empirical model for estimating phytoplankton productivity in estuaries. Mar Ecol Prog Ser 36:299-305

Di Toro DM (1978) Optics of turbid estuarine waters: approximations and applications. Water Res 12(12):1059-1068

Grant WD, Madsen OS (1979) Combined wave and current interaction with a rough bottom. J Geophys Res 84(C4): 1791-1808

Gross ES, Koseff JR, Monismith SG (1999) Three-dimensional salinity simulations of south San Francisco Bay. J Hydraul Eng 125(11):1199-1209

Foreman MGG (1978) Manual for tidal currents analysis and prediction. Pacific Mar Sci Report No 78-6. Institute of Ocean Sciences, Patricia Bay, Sidney, British Columbia

Koseff JR, Holen JK, Monismith SG, Cloern JE (1993) Cou- 
pled effects of vertical mixing and benthic grazing on phytoplankton populations in shallow, turbid estuaries. J Mar Res 51(4):843-868

Krone RB (1962) Flume studies of the transport of sediment in estuarial shoaling processes. Final Report, Hydraulic Eng Lab, University of California, Berkeley

Lucas LV (1997) A numerical investigation of coupled hydrodynamic and phytoplankton dynamics in shallow estuaries. PhD thesis, Stanford University, Stanford, CA

Lucas LV, Cloern JE (2002) Effects of tidal shallowing and deepening on phytoplankton dynamics: a modeling study. Estuaries 25(4):457-507

Lucas LV, Cloern JE, Koseff JR, Monismith SG, Thompson JK (1998) Does the Sverdrup critical depth model explain bloom dynamics in estuaries? J Mar Res 56(2):375-415

Lucas LV, Koseff JR, Cloern JE, Monismith SG, Thompson JK (1999a) Processes governing phytoplankton blooms in estuaries. I: The local production-loss balance. Mar Ecol Prog Ser 187:1-15

Lucas LV, Koseff JR, Monismith SG, Cloern JE, Thompson JK (1999b) Processes governing phytoplankton blooms in estuaries. II: The role of horizontal transport. Mar Ecol Prog Ser 187:17-30

McCormack RW, Paullay AJ (1972) Computational efficiency by time splitting of finite differential equations. AIAA Paper, p 72-154

McDonald ET, Cheng RT (1996) A numerical model of sediment transport applied to San Francisco Bay, CA. J Mar Environ Eng 4:1-41

McPherson BF, Miller RL (1994) Causes of light attenuation in Tampa Bay and Charlotte Harbor, Southwestern Florida. Water Resour Bull 30(1):43-53

Mellor GL, Yamada T (1982) Development of a turbulence closure model for geophysical fluid problems. Rev Geophys Space Phys 20(4):851-875

Monismith SG, Burau JR, Stacy MT (1996) Stratification dynamics and gravitational circulation in Northern San Francisco Bay. In: Hollibaugh JT (ed) San Francisco Bay: the ecosystem. AAAS, San Francisco, p 123-153

Editorial responsibility: Otto Kinne (Editor),

Oldendorf/Luhe, Germany
NRC (National Research Council) (2000) Clean coastal waters, understanding and reducing the effects of nutrient pollution. National Academy Press, Washington, DC

Örnólfsdóttir EB (2002) The ecological role of small phytoplankton in phytoplankton production and community composition in Galveston Bay, Texas. PhD thesis, Texas A\&M University, College Station, TX

Ruhl CA, Schoellhamer DH, Stumpf RP, Lindsay CL (2001) Combined use of remote sensing and continuous monitoring to analyse the variability of suspended-sediment concentrations in San Francisco Bay, California. Estuar Coast Shelf Sci 53:801-812

Sanford LP (1994) Wave-forced resuspension of upper Chesapeake Bay muds. Estuaries 17(18):148-165

Schoellhamer DH (1996) Factors affecting suspended-solids concentrations in South San Francisco Bay, California. J Geophys Res 101(C5):12087-12095

Simpson JH, Brown J, Mathews J, Allen G (1990) Tidal straining, density currents, and stirring in the control of estuarine stratification. Estuaries 13(2):125-132

Thompson JK (1999) The effect of infaunal bivalve grazing on phytoplankton bloom development in south San Francisco Bay. PhD thesis, Stanford University, Stanford, CA

USACE (United States Army Corp of Engineers) (1984) Shore protection manual, Vol 1. Coastal Engineering Research Center, Department of the Army, Waterways Experiment Station, Corps of Engineers, Vicksburg, MS

Vant WN (1990) Causes of light attenuation in nine New England estuaries. Estuar Coast Shelf Sci 31:125-137

Varela RA, Figueiras FG, Arbones B, Agustil S (1998) Determining the contribution of pigments and the nonalgal fractions to total absorption: toward and improved algorithm. Limnol Oceanogr 43(3):449-457

Webb WL, Newton M, Starr D (1974) Carbon dioxide exchange of Alnus-rubra: mathematical model. Oecologia $17(4): 281-291$

Wong KC (1994) On the nature of transverse variability in a coastal plain estuary. J Geophys Res C Oceans 99(7): 14209-14222

Submitted: February 14, 2002; Accepted: January 17, 2003 Proofs received from author(s): May 12, 2003 